Karstenia 39: 11-32, 1999

\title{
The Stropharia semiglobata group in NW Europe
}

\author{
ILKKA KYTÖVUORI
}

Kytövuori, I. 1999: The Stropharia semiglobata group in NW Europe. - Karstenia 39:11-32. Helsinki. ISSN 0435-3402

Six species are recognized in the Stropharia semiglobata group in NW Europe: S. alcis Kytöv., spec. nova, S. arctica Kytöv., spec. nova, S. dorsipora Esteve-Rav. \& Barrasa, S. islandica Kytöv., spec. nova, S. luteonitens (Vahl : Fr.) Quél. and S. semiglobata (Batsch : Fr.) Quél. S. semiglobata is common throughout the study area and S. alcis in Fennoscandia, $S$. dorsipora and $S$. luteonitens are rare or very rare and possibly decreasing in Fennoscandia, $S$. islandica is known from Iceland, and S. arctica from Iceland and arctic Russia. The distribution of each species in the study area is mapped, and their taxonomy, ecology and relationships are discussed.

Key words: Stropharia, Psilocybe, coprophilous, Fennoscandia, mapping, taxonomy.

Ilkka Kytövuori, Department of Ecology and Systematics, P.O. Box 7 (Unioninkatu 44), FIN-00014 University of Helsinki, Finland

\section{Introduction}

The Stropharia semiglobata group, as interpreted by the present author, has commonly been supposed to be represented by two species in NW Europe, one, S. semiglobata, being very common and the other, $S$. luteonitens, very rare. When studying the material collected during the Tenth Nordic Mycological Congress at Hoverud, Sweden, in 1990, an existence of a third species in the group became evident to me. Subsequent studies showed the group to be still more complicated and revealed six species instead of the two commonly recognized. Meanwhile one of them has been described as new, viz. S. dorsipora Esteve-Rav. \& Barrasa (Esteve-Raventós \& Barrasa 1995).

\section{Material and methods}

Specimens were checked in the following herbaria: AMNH, BG, C, H, JOE, JYV, KUO, MA, O, OULU, S, UME, UPS, TRH, TROM, TUR and TURA (the symbols are those of Holmgren et al. 1990).
Microscopical characteristics were examined under a Leitz Labourlux 12 microscope, at magnifications of about 625 and 1560 . Spores, basidia and cystidia were drawn with a Leitz drawing tube at a magnification of 2000. Spores were examined, measured (with an ocular micrometer) and drawn from slides showing the surface view of pieces of gills of dried basidiocarps, mounted in Melzer's reagent. Only spores in a horizontal position were measured; young, anomalous, very small or gigantic spores were excluded. Length and width were measured from the same spore, and the length/width ratios were calculated for individual spores.

Basidia and cystidia were drawn from slides with squashes of gill pieces mounted in Melzer's reagent. Measurements were mostly made from drawings. Pileipellis and stipitipellis were examined from slides with small scalps or from sections of dried basidiocarps made (without moistening) with a razor blade, mounted in Melzer's reagent. 


\section{Key to species}

1 Stipe dry, not very long and slender, spores $<12 \times 7 \mu \mathrm{m}$............... Stropharia spp. (not treated)

- Stipe viscid to slimy, long and slender, spores $>12 \times 7 \mu \mathrm{m}$.................................................... 2

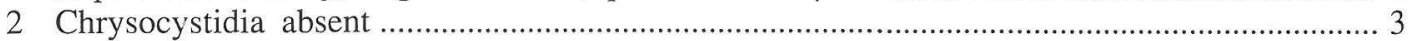

- Chrysocystidia present, basidia 4-spored ............................................................................... 4

3 Basidia 4-spored ................................................................................. 5. Stropharia islandica

- Basidia 2-spored .................................................................................................. 6. S. luteonitens

4 On elk dung, spores mostly $<8.3 \mu$ m wide ............................................................ 3. S. alcis

- Mostly on dung of cow or horse, or on manured soil, spores mostly $>8.3 \mu \mathrm{m}$ wide .................. 5

5 Chrysocystidia abundant on stipe, spores with large, central germ pore .......... 1. S. semiglobata

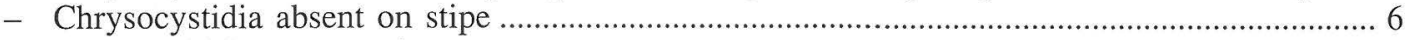

6 Spores with large, central germ pore …................................................................... 4. S. arctica

- Spores with smaller, dorsal germ pore ................................................................. 2. S. dorsipora

\section{Stropharia semiglobata (Batsch : Fr.) Quél. (Figs. 1, 3 6-9)}

Stropharia semiglobata (Batsch : Fr.) Quél., Champ. Jura et Vosges 1:143. 1872. - Agaricus semiglobatus Batsch, Elench. Fung. Cont. 1:141, pl. 21, fig. 110. 1786; Fr. Syst. Mycol. 1:284. 1821. - Geophila semiglobata (Batsch : Fr.) Quél., Enchir. Fung. 112. 1886. Type: not typified.

Stropharia stercoraria (Schumach. : Fr.) Quél., Champ. Jura et Vosges 1:143. 1872. - Agaricus stercorarius Schumach., Enum. Pl. 2:286. 1803; Fr. Syst. Mycol. 1:291. 1821. - Geophila stercoraria (Schumach. : Fr.) Quél., Enchir. Fung. 112. 1886. - S. semiglobata var. stercoraria (Schumach. : Fr.) J.E. Lange, Fl. Agaric. Danica 4:67, 1939. - Type: not typified.

Illustrations: Cooke (1884: pls. 538 as Agaricus stercorarius, 539), Ricken (1915: pl. 63), Konrad \& Maublanc (1924: pl. 55), Bresadola (1931: pls. 838 as S. stercoraria, 839) Lange (1935: pls. 142A, 142D), Michael et al. (1985: figs. 253, 254), Phillips (1981: 171), Dähncke (1993: 602, 603).

Pileus $1-4.5 \mathrm{~cm}$, hemispherical to broadly subglobose with or without a low, broad umbo, expanding broadly convex, viscid to strongly glutinous, straw yellow, ochraceous at the disk. Lamellae segmentiform or slightly arcuate at first, later fairly broad, subventricose, slightly decurrent to adnate to shallowly emarginate with a low tooth, somewhat greenish blackish to blackish brownish with white edge, mostly three lamellulae between the whole ones. Stipe 3-15 cm, slightly evenly thickening towards the mostly somewhat clavate base, $1.8-5 \mathrm{~mm}$ thick at the apex, 2.5-7 $\mathrm{mm}$ thick at the base, hollow, with a narrow cavity, with a thin, rudimentary, glutinous annulus $0.5-3(-5) \mathrm{cm}$ below the gills, white straw yellowish and strongly glutinous below, dry and somewhat whitish pruinose above the ring zone. Smell none, taste mild.

Spores $15.4-21.3 \times 9.1-11.3 \mu \mathrm{m}(\overline{\mathrm{x}}=16.2-19.6 \times$

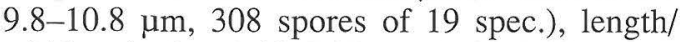
width ratio $\mathrm{Q}=1.64-2.00(\overline{\mathrm{q}}=1.69-1.88)$, ellipsoid, very slightly flattened ventrally (adaxially), smooth, bay to dark brick in Melzer's reagent, thick-walled, with some guttules mostly at both ends, germ pore distinct, central, 2.0-2.5 $\mu \mathrm{m}$ wide.

Basidia broadly clavate, $28-40(-46) \times 11-15$ $\mu \mathrm{m}$ (74 bas. of $13 \mathrm{spec}$.), 4-spored with broad sterigmata. Pleurocystidia chrysocystidia, mostly broadly clavate, $33-52 \times 11.5-16.5 \mu \mathrm{m}$ (184 chrysoc. of $20 \mathrm{spec}$.), apex rounded obtuse to broadly mucronate, with orange brown inclusion in Melzer's reagent, fairly abundant, mostly present at gill edge. Cheilocystidia narrowly lageniform, $34-59 \mu \mathrm{m}$ long ( $230 \mathrm{cheiloc}$. of $21 \mathrm{spec}$.), with 5.510.5 thick base and long, 3-6 $\mu \mathrm{m}$ thick, mostly straight apical part, which may be slightly tapering or very indistinctly swollen just at the apex (sometimes even subcapitate) but not clavate; evenly distributed at the edge. Gill edge sterile.

Caulocystidia on stipe top in form like cheilocystidia, 37-72 um (64 cauloc. of 7 spec.), in fascicles. Chrysocystidia present on the whole stipe; on the top above the ring in form similar as those on gills but somewhat smaller, patent, between the hyaline cystidia; on the slimy part below the ring variable in form and size, closely appressed, wholly deeply embedded in the slime, most numerous at the stipe base (checked from 85 specimens). 
Cap cuticle an ixocutis with thick slime layer with few, 1.5-4 $\mu$ m thick, embedded hyphae, in the lower part with somewhat thicker (to $7 \mu \mathrm{m}$ ), not (or very finely) encrusted. Stipe cuticle an ixocutis as in the cap but hyphae more numerous, near the surface 2-4 $\mu$ m thick, deeper a little thicker (to $5 \mu \mathrm{m}$ ), not or very finely spirally encrusted, encrustation strongest at the stipe base. Clamps present at all septa.

\section{Ecology and distribution}

In Finland Stropharia semiglobata most often grows on decayed dung of cow or horse in pastures or in newly manured soil. In the material of Arnolds (1982) the dung of sheep was the most important substrate, but that dung appears very seldom in the present material. Some collections are also from decayed elk dung in forests (Fig. 7). Nowadays cattle is in Finland mostly grazed in fairly young, heavily fertilized hay fields, and the rotation is too quick for coprophilous basidiomycetes. According to Arnolds (1982) the use of artificial fertilizers strongly diminishes the occurrence of $S$. semiglobata. The species is commonest in older, more extensively grazed pastures or in woodland pastures, which, however, are now rare in Finland. Near stables there are suitable places such as training or riding tracks, but the pastures proper are often too intensively grazed.

The growing period of Stropharia semigloba$t a$ is long (practically all the time when ground is free of snow or frost), but the optimum seems to be from the middle of July to the end of September (Fig. 9). Single collections have made in February (Denmark), in March and April (Finland, Iceland) and in December (Iceland).

First collection of Stropharia semiglobata in the material examined is from the year 1843 (Gottlund, H). Thereafter collections have been made in all decades (except the 1910's), and the amount increased strongly after the Second World War (Fig. 8). The high peak in the 1960's is evidently due to the activities in the new research station at Kevo (in Utsjoki, northernmost Finland) and the new herbaria of OULU (North Finland) and AMNH (Iceland). That peak is not seen in the other species treated here.

Stropharia semiglobata is fairly common throughout the NW Europe (Fig. 1), but has nowadays somewhat reverted in most areas owing to the changes in the countryside living (diminishing of woodland pastures and disappearing of horses in forestry and agricultural work). In forest regions it is rare and replaced by $S$. alcis. The gaps in the map in Swedish and Finnish Lapland, at least, may be real. Along the Norwegian coast, in Iceland and in the Faeroes it is common. Farther south in Europe S. semiglobata is common (e.g. Kreisel 1987, Krieglsteiner 1991, Watling \& Gregory 1987), but that information includes also $S$. dorsipora. According to the collections in herbaria and my own experience in the field S. semiglobata s.str. is nowadays less common in Central Europe than in the north.

\section{Discussion}

Stropharia semiglobata is easily recognized by its large spores with large, central germ pore, narrowly lageniform cheilocystidia and presence of chrysocystidia on the stipe. S. dorsipora also has large spores but with eccentric germ pore, $S$. alcis distinctly smaller spores and apically swollen cheilocystidia, $S$. arctica smaller spores and narrowly clavate cheilocystidia. All the three latter lack chrysocystidia on the stipe. S. luteonitens and $S$. islandica lack chrysocystidia wholly. Also species of Psilocybe merdaria group can be similar, but those have dry stipe, smaller and slightly hexagonal spores and lack chrysocystidia.

Two names, Stropharia semiglobata and $S$. stercoraria, have long been used in the present species group. They are treated as different species in e.g. Schumacher (1803), Fries (1821, 1836, 1874), Cooke (1871, 1884), Quélet $(1872,1886)$, Gillet (1878), Karsten (1879), Saccardo (1887), Ricken (1915), Kauffman (1918), Rea (1922), Lange (1923) and Bresadola (1931). Later S. stercoraria has been reduced to the varietal level or noticed not at all (e.g. Konrad \& Maublanc 1924, Lange 1935, Arnolds 1982, Michael et al. 1985, Kreisel 1987, Moser 1983, Watling \& Gregory 1987, Krieglsteiner 1991). The separating characteristics are obscure and contradictory and all forms are well represented in the present material of $S$. semiglobata s.str. Thus both the epithets above must be regarded as synonyms and neither of them can be applied to the other species treated here.

Karsten (1882) described a dry-stiped form Stropharia semiglobata subsp. siccipes (treat- 


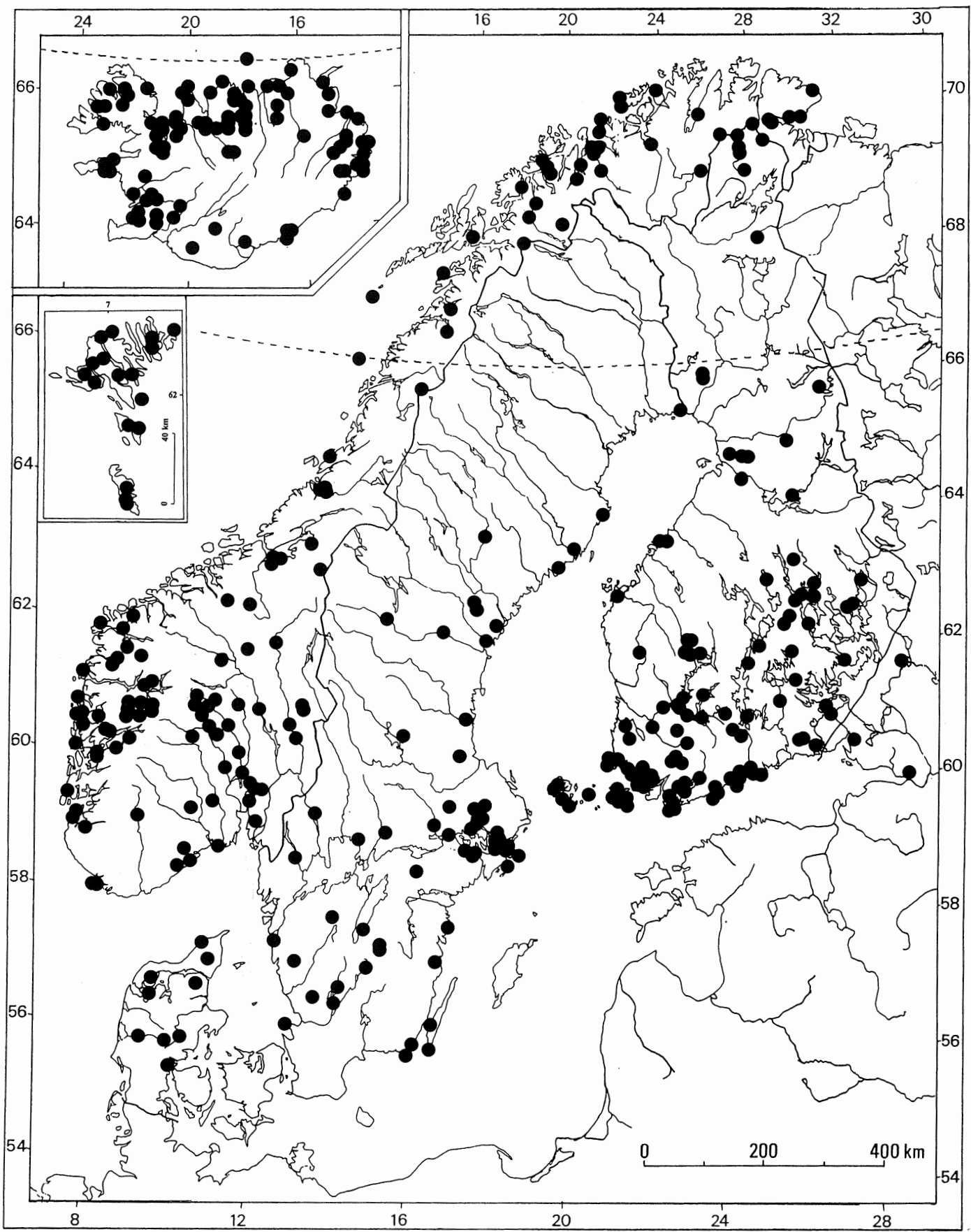

Fig. 1. Distribution of Stropharia semiglobata in NW Europe according to the material examined. 


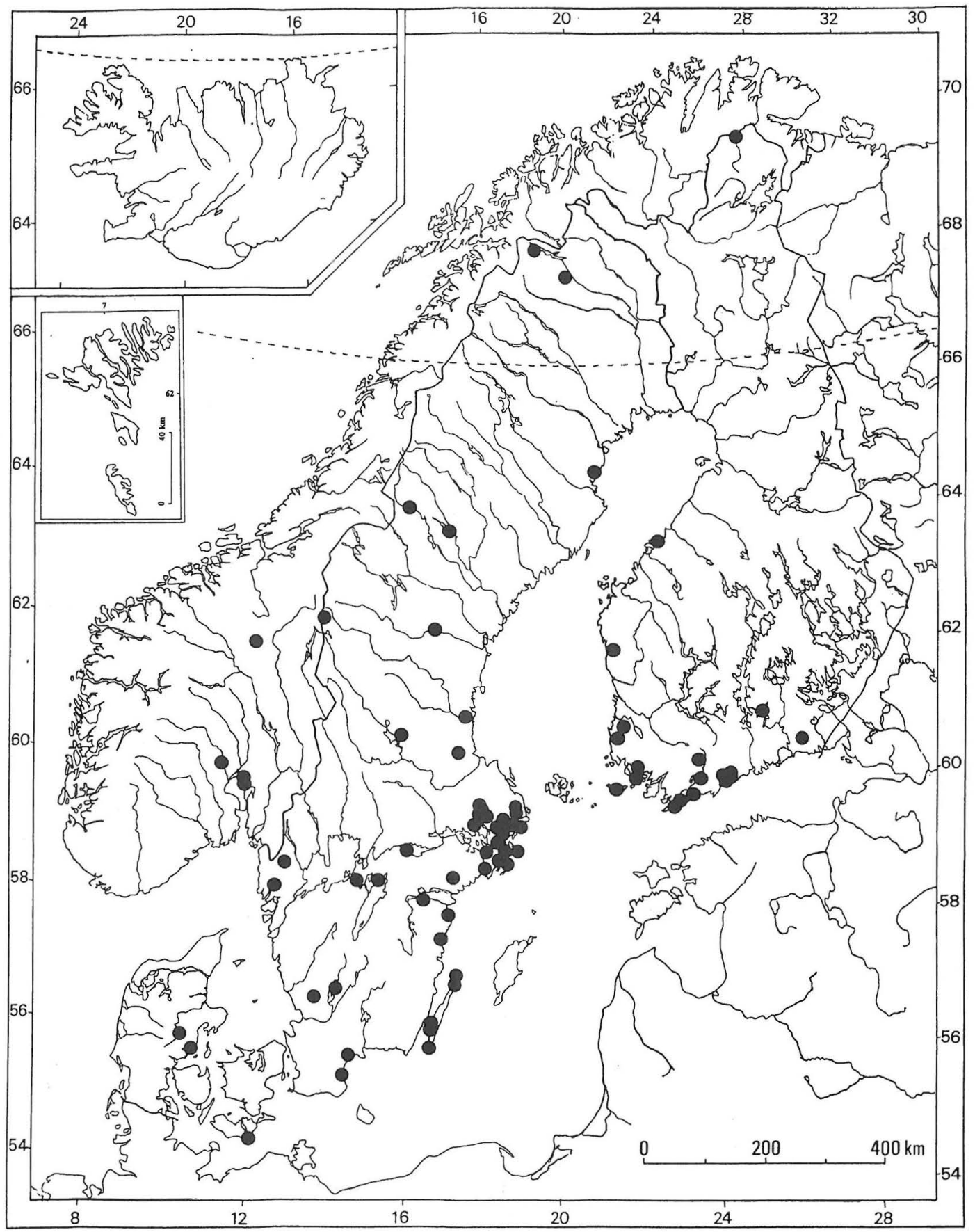

Fig. 2. Distribution of Stropharia dorsipora in NW Europe according to the material examined. 
ed as species by Saccardo 1887) as an intermediate between $S$. semiglobata and S. stercoraria. However, according to the type, it belongs to the Psilocybe merdaria group.

Specimens examined: Iceland. 118 ex. leg. Hallgrímsson (AMNH), 1 ex. (C), 1 ex. (O). Denmark. 28 ex. (C, incl. 20 ex. from Faeroes) 5 ex. (H), 4 ex. (Faeroes, KUO). Norway. 30 ex. (BG), 5 ex. (H), 81 ex. (O), 1 ex. (OULU), 5 ex. (TRH), 42 ex. (TROM), 2 ex. (TUR). Sweden. Fungi Exs. Suec. Ups., ed. Lundell \& Nannfeldt, no. 1143, from Småland, Femsjö, is a mixed collection of $S$. semiglobata and $S$. dorsipora (examined from $\mathrm{C}$ and S). 3 ex. (C), 10 ex. (H), 57 ex. (S, ), 1 ex. (UME), 27 ex. (UPS, incl. 5 moist chamber cultivations of N. Lundqvist). Finland. 1 ex. (C), 106 ex. (H), 4 ex. (KUO), 14 ex. (OULU), 51 ex. (TUR), 13 ex. (TURA). Russia. 3 ex. (H), 1 ex. (S). Great Britain. 1 ex. (S). Germany. 1 ex. (H). France. 1 ex. (H). Italy. 5 ex. (herb. Bresadola, S).

\section{Stropharia dorsipora Esteve-Rav. \&} Barrasa (Figs. 2, 4, 6-9)

Stropharia dorsipora Esteve-Rav. \& Barrasa, Rev. Iberoamer. Micol. 12:71. 1995. - Type: Spain, El Barco de Avila, in stercore vaccino, 11.V.1974 G. López (MAFungi 32018). Examined.

Pileus smaller than in Stropharia semiglobata, $0.5-2.5(-4)$, hemispherical with a broad umbo, expanding rounded convex, straw-coloured to yellowish brownish, viscid to glutinous. Lamellae segmentiform to somewhat arcuate to subventricose, adnate to shallowly emarginate with a low tooth, somewhat brownish blackish with white edge. Stipe fairly short, 2-10 cm long, slenderer than in $S$. semiglobata, straw-coloured, viscid, annulus ascending at least at first, more persisting and distinct than in most other species treated here, $0.6-3.5 \mathrm{~cm}$ below the gills (relatively lower down than in S. semiglobata, sometimes near the middle of the stem). The description above is based on dried specimens, but the dimensions agree fairly well with the fresh material, too, because fairly many collections contain basidiocarps longitudinally sectioned and then pressed and dried between papers in the same manner as phanerogams.

Spores $15.9-20.4(-22) \times 9.1-11.6 \mu \mathrm{m}(\overline{\mathrm{x}}=17.2-$ $19.5 \times 9.8-11.0,401$ spores of $23 \mathrm{spec}$.), length/ width ratio $\mathrm{Q}=1.61-1.91(\overline{\mathrm{q}}=1.71-1.80)$, very slightly ovoidly ellipsoid in face view, slightly ventrally flattened, brick reddish brown to umber in Melzer's reagent, with darker colour and thicker wall than those in $S$. semiglobata, germ pore dorsal (abaxial) and/or slightly eccentric sideways, $1.2-1.7 \mu \mathrm{m}$ wide, clearly smaller and less distinct than in $S$. semiglobata. The eccentric dorsal germ pore is usually well demonstrated when the spore is seen exactly in profile.

Basidia broadly clavate, $30-42 \times 11.5-14.5 \mu \mathrm{m}$ (71 bas. of 12 spec.), 4-spored, with broad sterigmata. Pleurocystidia chrysocystidia, 30-50 $\times$ 11-16 um (196 chrysoc. of 13 spec.), clavate with mostly mucronate to rostrate apex and yellowish brown inclusion, scarcer than in S. semiglobata, mostly absent at gill edge. Cheilocystidia 26-50 $\mu \mathrm{m}$ (310 cheiloc. of $14 \mathrm{spec}$.), in form between those of $S$. semiglobata and $S$. alcis, with base 4.5-10 $\mu \mathrm{m}$ thick, middle part 2.5-6 $\mu \mathrm{m}$ thick, almost straight to distinctly flexuous and apex somewhat swollen 3-7 $\mu$ m thick, evenly distributed on the edge. Gill edge sterile. Caulocystidia on the stipe top above the ring zone similar with cheilocystidia, 25-62 $\mu \mathrm{m}$ long (65 cauloc. of 5 spec.). Chrysocystidia absent on the stipe, both on the top above and on the slimy part below the ring (checked from 55 specimens).

Cap cuticle an ixocutis with thick slime layer with few, 2-4 $\mu \mathrm{m}$ thick, embedded hyphae, in the lower part somewhat thicker (to $7 \mu \mathrm{m}$ ), not (or very finely) encrusted. Stipe cuticle an ixocutis as in the cap but hyphae more numerous, near the surface 2-4 $\mu \mathrm{m}$ thick, deeper a little thicker (to $5 \mu \mathrm{m}$ ), not or very finely spirally encrusted, encrustation strongest at the stipe base. Clampconnections present at all septa.

\section{Ecology and distribution}

According to the present material Stropharia dorsipora favours horse dung, some specimens being collected from cow dung and some from manured soil (Fig. 7). In ten collections information is only "on dung" and the rest are without exact information. The collections are (when informed) from dryish meadows, road sides, open or woodland pastures or yards. 17 specimens are mixed with $S$. semiglobata, but it is unknown, whether the basidiocarps have grown on exactly same dung heaps.

Stropharia dorsipora seems to produce basidiocarps fairly evenly throughout the warm period of the year from the beginning of May to the end of October with a slight optimum in the midsummer (Fig. 9). 
The first collections of Stropharia dorsipora in the material studied are from the 1890's. Most of collections are from between the years 1940 and 1961. The history of the species differs strikingly from that of the most other species treated here. The vast majority of the specimens of $S$. semiglobata and especially $S$. alcis has been gathered after 1960. That maximum cannot at all be seen in the material of S. dorsipora (Fig. 8). After the 1950's horse is completely replaced with machines in forestry and agricultural work in Fennoscandia. In the same time $S$. dorsipora seems to have disappeared or become rare.

Stropharia dorsipora seems nowadays to be a fairly rare species in Finland. Most of the collections are from the coastal areas. Only one is from farther from the southern interior (EteläHäme, Heinola, 1977 Vainio 29, H), from a town lawn. New lawns in public parks and roadsides in towns and villages, set up on nutrient rich composted community waste, may offer a new possible habitat to that species. Many other coprophilous fungi are often abundant on such new lawns. One solitary record is known from Utsjoki in northernmost Lapland (Fig. 2).

In Scandinavia Stropharia dorsipora has been fairly common in the eastern part, from Uppland to Öland. Outside that area only sporadic collections exist, the northernmost at Abisko in Torne Lappmark (Fig. 2). Obviously the species is declining also in Scandinavia, but it is not known in certainty because the whole group is poorly collected during the last years in Sweden. I myself have never seen the species in Sweden. In Norway it is rare and known in the SE part only. In Denmark it seems to be commoner but more material is needed.

In Europe outside Fennoscandia Stropharia dorsipora is known from Germany $(\mathrm{H})$, Netherlands (Noordeloos 1996), Great Britain (H), France (H, S), Switzerland (Noordeloos 1996), Greece (O), Italy (S) and Spain (Esteve-Raventós $\&$ Barrasa 1995). Outside Europe the species is known from Lake Baical region, in Russian Asia $(\mathrm{H})$, and from New York (S) and California (Noordeloos 1996) in America.

In view of the small material outside the study area specimens of $S$. dorsipora are much more numerous from there than from Fennoscandia when compared with S. semiglobata. The former is a southern species in Fennoscandia and seems to be clearly commoner farther in the south.

\section{Discussion}

Stropharia dorsipora is best recognized by the combination of large, dark-coloured spores with an eccentric dorsal germ pore and presence of chrysocystidia (however, lacking on the stipe). Macroscopically the more distinct ring is distinctive.

Stropharia dorsipora was included in the scope of S. semiglobata and S. stercoraria in old literature, but because either of them can be fixed for the present species (cf. discussion under $S$. semiglobata), the creation of a new name, $S$.dorsipora, by Esteve-Raventós \& Barrasa (1995) is well justified. The different habitat - cow dung against that of horse - is most likely due to their very small material.

Specimens examined: Denmark. 6 ex. (C). Norway. 1 ex. (H), 3 ex. (O). Sweden. Fungi Exs. Suec. Ups., ed. Lundell \& Nannfeldt, no. 1143, from Småland, Femsjö, is a mixed collection of $S$. semiglobata and $S$. dorsipora (examined from $\mathrm{C}$ and S). 51 ex. (S), 30 ex. (UPS, incl. 13 moist chamber cultivations of N. Lundqvist). Finland. 34 ex. (H), 3 ex. (OULU), 5 ex. (TUR). Russia. 1 ex. $(\mathrm{H})$. Great Britain. 1 ex. $(\mathrm{H})$. Germany. 1 ex. (H). France. 1 ex. (H). Hungary. 1 ex. (C). Italy. 7 ex. herb. Bresadola (S). Spain. Type (MA). Greece. 1 ex. (O). U.S.A. 1 ex. (S).

\section{Stropharia alcis Kytöv., spec. nova} (Figs. 4, 6-10)

Illustrations: Ryman \& Holmåsen 1984: 441 (as Stropharia semiglobata).

Facie graciliore, colore quasi lutescenti, sporis aliquantum minoribus $(12.5-16.3 \times 7.0-8.6$ $\mu \mathrm{m})$, cheilocystidiis anguste clavatis, stipite chrysocystidiis nullis, et habitatione in fimo alcis (Alces alces) a Stropharia semiglobata distinctus. In silvis borealibus Fennoscandiae frequens.

Holotypus: Finland, Koillismaa, Kuusamo, Jussinlamminvaara, rich spruce-hardwood forest with open, spring-fed, low eutrophic depressions, on elk dung, 2.IX.1992 Kytövuori 92$1530(\mathrm{H})$.

Pileus $1-5.5 \mathrm{~cm}$, hemispherical to broadly subglobose with a very low, broad umbo, later broadly convex, viscid to strongly glutinous, straw yellow, ochraceous at the disk, slightly more vivid than in Stropharia semiglobata. Lamellae segmentiform or slightly arcuate at first, later fairly broad, subventricose, adnate to shallowly 

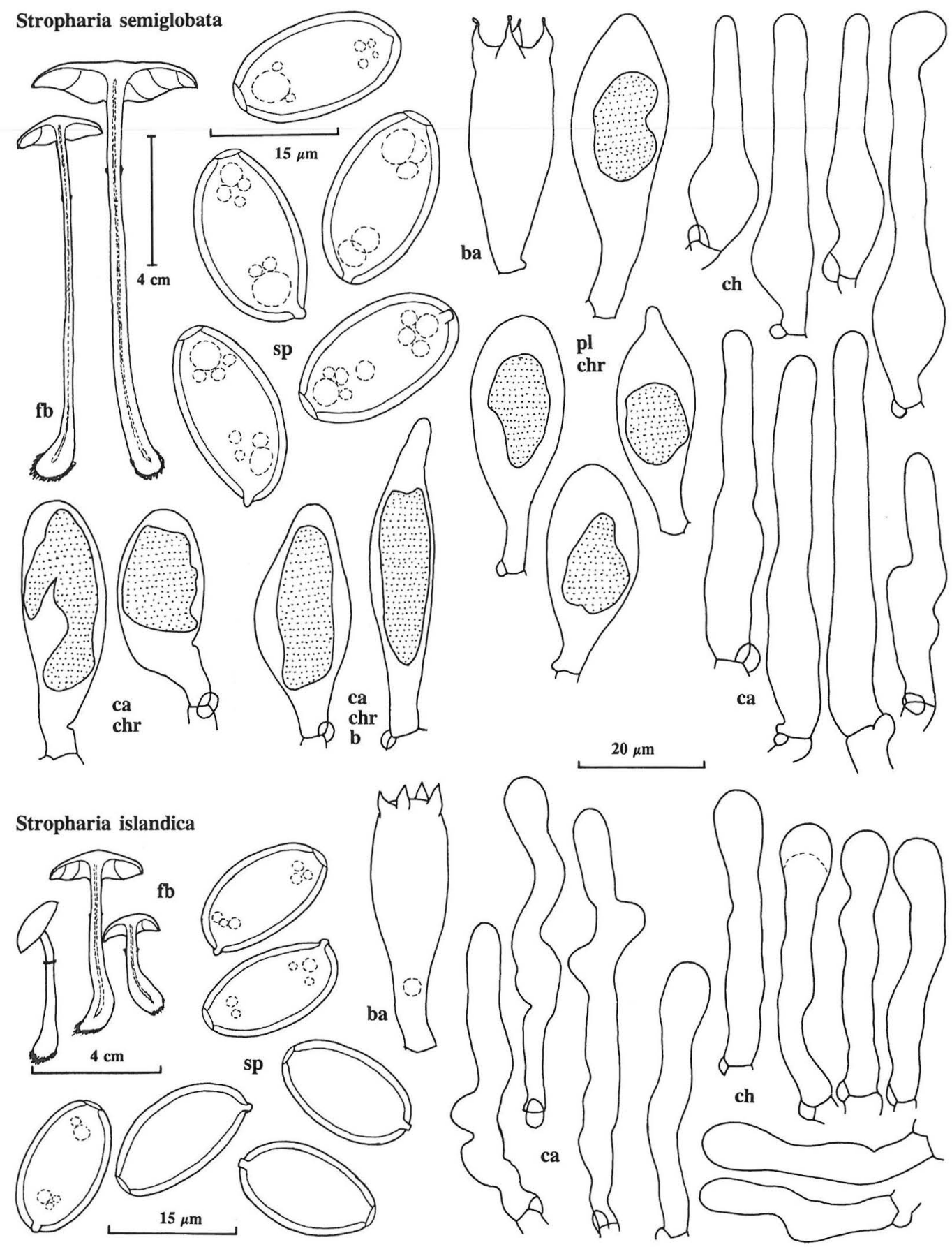

Fig. 3. Fruitbodies and microscopical details. Stropharia semiglobata: Finland, Keski-Pohjanmaa, Kokkola, 1951 (left) and 1952 (right) Rauhala (H, fruitbodies); Finland, Pohjois-Savo, Mikkeli r.c., Kytövuori 92-2691 (H, microscopical details). S. islandica: Iceland, Eyjafjardar Sýsla, Glerardalur, Hallgrímsson 5323 (AMNH, type). - ba: basidia, ca: caulocystidia (b: from stipe base; otherwise from the top), ch: cheilocystidia, chr: chrysocystidia, fb: fruitbodies, pl: pleurocystidia, sp: spores. Scale: fruitbodies $\times 0.5$, cystidia $\times 1000$, spores $\times 1500$. 

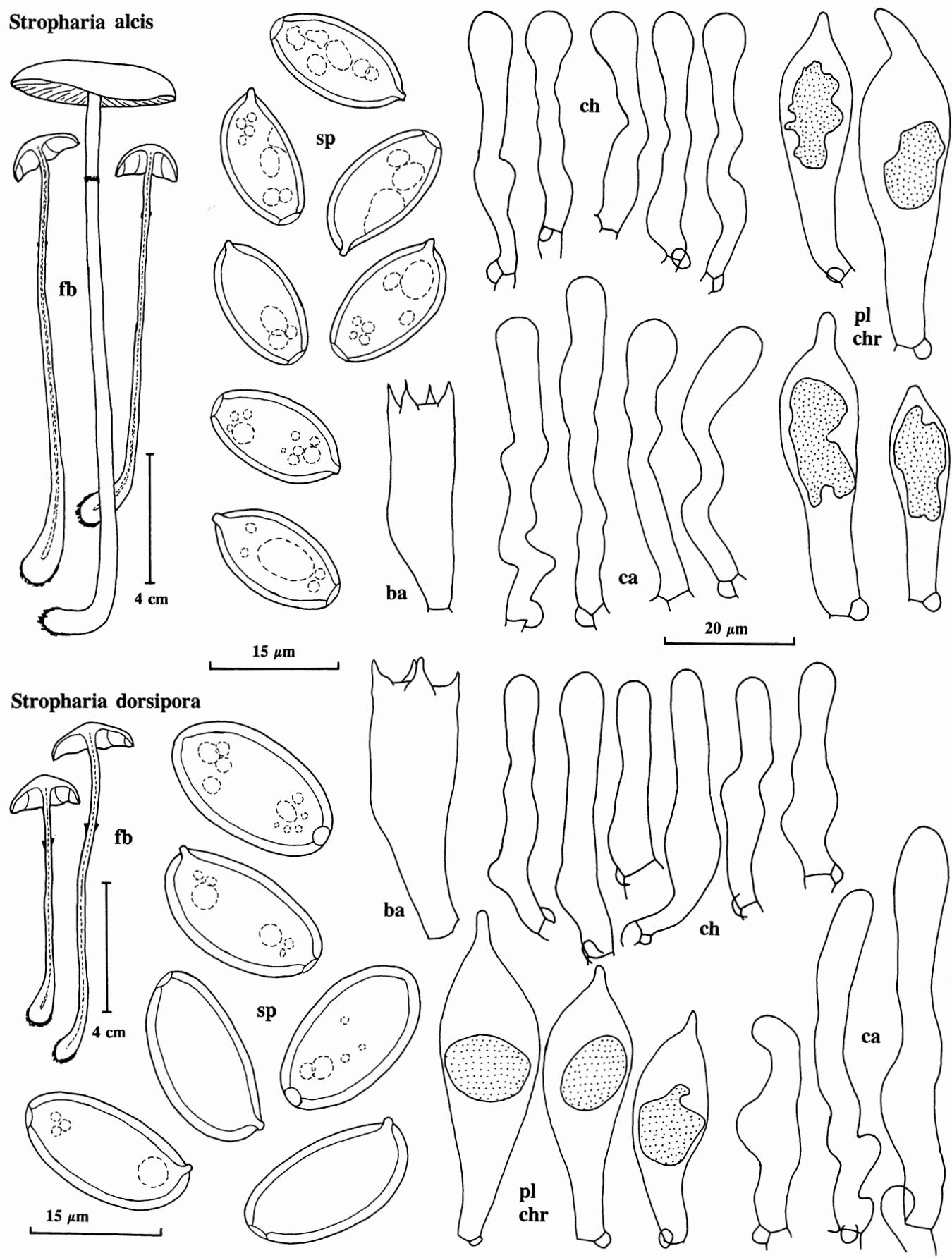

Fig. 4. Fruitbodies and microscopical details. Stropharia alcis: Finland, Koillismaa, Kuusamo, Kytövuori 92-1530 (H, type). S. dorsipora: Finland, Keski-Pohjanmaa, Kokkola, 17.VII.1951 (left) and 22.VII.1951 (right) Rauhala (H, fruitbodies); Uusimaa, Espoo, Korhonen 6430 (H, microscopical details). - ba: basidia, ca: caulocystidia. ch: cheilocystidia, chr: chrysocystidia, fb: fruitbodies, pl: pleurocystidia, sp: spores. Scale: fruitbodies $\times 0.5$, cystidia $\times 1000$, spores $\times 1500$. 
emarginate with a low tooth, greenish blackish with white edge, mostly three (in large caps to 7) lamellulae between the whole ones. Stipe 3-17(22) $\mathrm{cm}$, slightly evenly thickening towards the mostly somewhat clavate base, $1.8-5 \mathrm{~mm}$ thick at the top, 2.5-7 mm thick at the base, hollow with a narrow cavity, with a thin, rudimentary, glutinous annulus $0.5-3(-5) \mathrm{cm}$ below the gills, pale yellow and strongly glutinous below, dry and somewhat whitish pruinose above the ring zone. The stipe is relatively longer, more brightly coloured and the annulus more above than those of S. semiglobata. Smell none, taste mild.

Spores $12.5-16.3 \times 7.0-8.6 \mu \mathrm{m}(\overline{\mathrm{x}} 13.5-15.2 \times$ $7.4-8.1,356$ spores of $20 \mathrm{spec}$.), length/width ratio $q=1.68-2.03(\bar{q} 1.74-1.93)$, slightly ovoidly ellipsoid, somewhat flattened ventrally (adaxially), smooth, umber in Melzer's reagent, thickwalled, with some guttules mostly at both ends, germ pore distinct, central, 1.8-2.0 $\mu \mathrm{m}$ (spores seem somewhat truncate owing to the relatively large germ pore).

Basidia broadly clavate, $27-35 \times 9.5-11.5 \mu \mathrm{m}$ (118 bas. of $16 \mathrm{spec}$.), 4-spored with fairly broad sterigmata. Pleurocystidia chrysocystidia, mostly broadly fusiform, $31-48 \times 9.5-13 \mu \mathrm{m}(120$ chrysoc. of 11 spec.), apex sometimes obtuse, most often broadly mucronate to shortly rostrate, with yellowish brown inclusion, scarcer than in Stropharia semiglobata, mostly absent at gill edge. Cheilocystidia narrowly clavate, 25$45 \mu \mathrm{m}$ long ( 275 cheiloc. of $18 \mathrm{spec}$.), with more or less swollen, 4.0-7.5 $\mu \mathrm{m}$ thick apex, but not distinctly capitate, middle part flexuous $2.5-4.0 \mu \mathrm{m}$ thick and base 3.5-6.5(-8.5) $\mu$ m thick; very abundant, in large, very dense fascicles. With dissecting microscope the gill edge of dried basidiocarps seems to be covered by white conglutinated lumps. Gill edge sterile. Caulocystidia on the stipe top above the ring zone similar with cheilocystidia, $29-50 \mu \mathrm{m}$ long (57 cauloc. of 4 spec.). Chrysocystidia lacking on the whole stipe (both on the slimy part below and on the dry top above the ring; checked from 50 specimens).

Cap cuticle an ixocutis with thick slime layer with few, 2-4 $\mu$ m thick, embedded hyphae, in the lower part somewhat thicker (to $7 \mu \mathrm{m}$ ), not (or very finely) encrusted. Stipe cuticle an ixocutis as in the cap but hyphae more numerous, near the surface 2-4 $\mu \mathrm{m}$ thick, deeper a little thicker (to $5 \mu \mathrm{m}$ ), hardly encrusted, encrustation strongest at the stipe base. Clamps present at all septa.

\section{Ecology and distribution}

Stropharia alcis grows most often in conifer forests on more or less decayed dung heaps of elk (Alces alces). Elk dung decays slowly. Gradually the heap may become covered by a dense cluster of $S$. alcis, alone or mixed with other coprophilous agarics. Sometimes dense stands have been substituted by only few, but then very large basidiocarps (cf. Ohenoja 1976, Ryman \& Holmåsen 1984). When decaying goes on, the amount of nutrients decreases, and year after year the stands become scarcer and the basidiocarps smaller. I do not know, how long one dung heap may produce basidiocarps, but often small, solitary basidiocarps are still found on dung totally covered by moss carpet, even of Pleurozium, Hylocomium or Sphagnum.

Stropharia alcis seems nearly always grow on elk dung (Fig. 7). One specimen of the material studied has been collected from hare pellets. On the other, hand eight specimens of S. semiglobata have been collected from elk dung. Two of the latter collections are mixed with $S$. alcis, but it is not noted whether the basidiocarps have grown exactly on the same heap. In Fennoscandia cow grazing in forests is now rare, and horse is not used in forestry. Thus the dung Stropharias in forests are now generally represented by $S$. alcis, whereas S. semiglobata is to be found on cultivated land.

Stropharia alcis produces basidiocarps in Finland at the autumn from the beginning of August to the middle of October. The fruiting period seems to be shorter and the optimum later than in S. semiglobata (Fig. 9).

The first single Stropharia alcis collection in the present material dates from the year 1934 (Karjalohja, SW part of Finland, Frey, H). From Sweden the first collections are from the next decade (Uppland, Ö. Ryd, 1947 Berggren, S and Djurö, 1948 Rydberg, S). Thereafter the amount of collections has increased quickly and in recent years the species has been the most collected of the group (Fig. 8).

In the last century elk was rare in Finland and after World War I it disappeared totally from most part of the country, and also in Scandinavia the population was scanty and not continuous. Elk population began to increase in 1920's in Sweden and 1930's in Finland. Particularly conspicuous the increase was in the 1970's. Thereafter the pop- 
Stropharia arctica
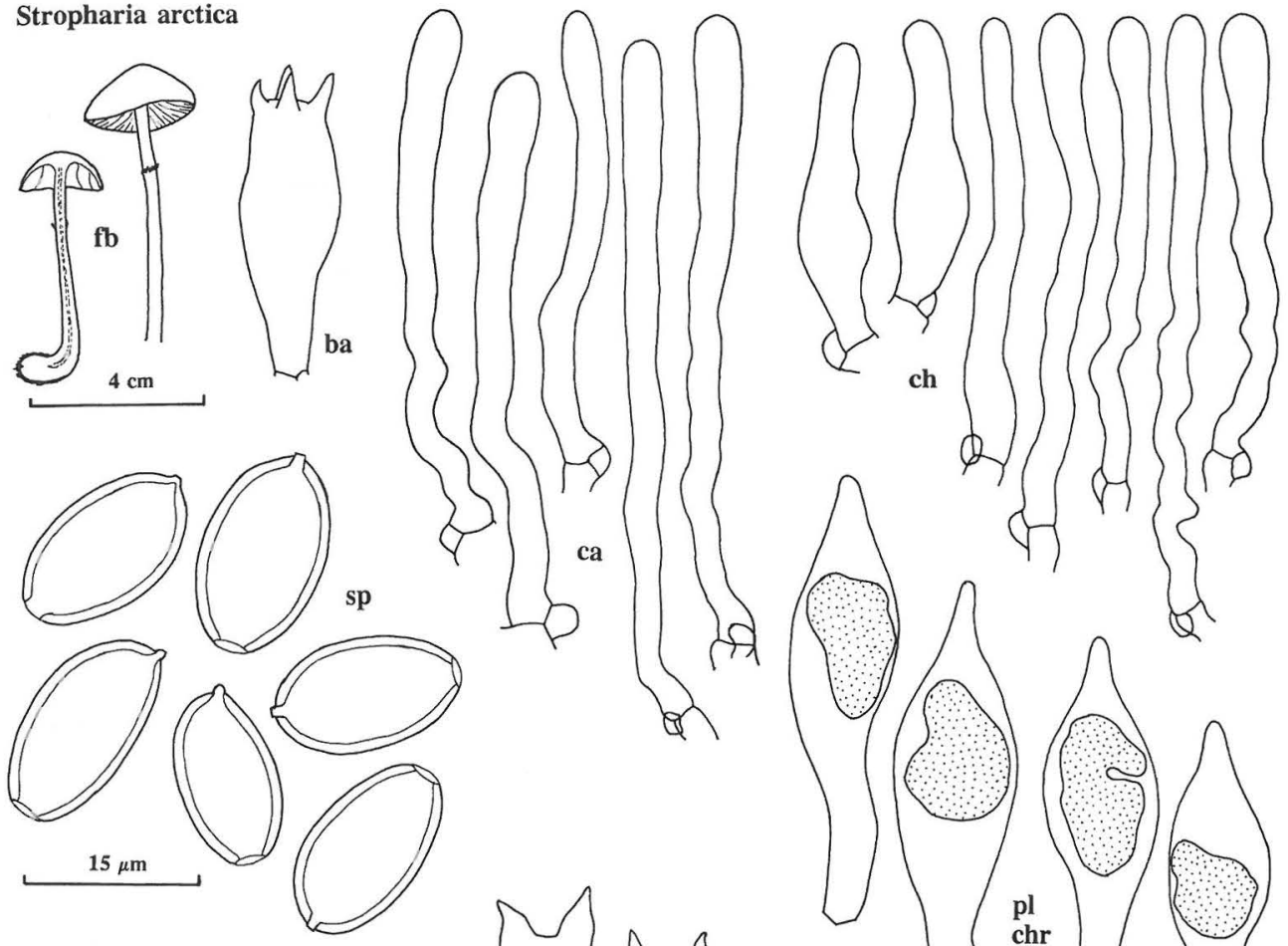

Stropharia luteonitens
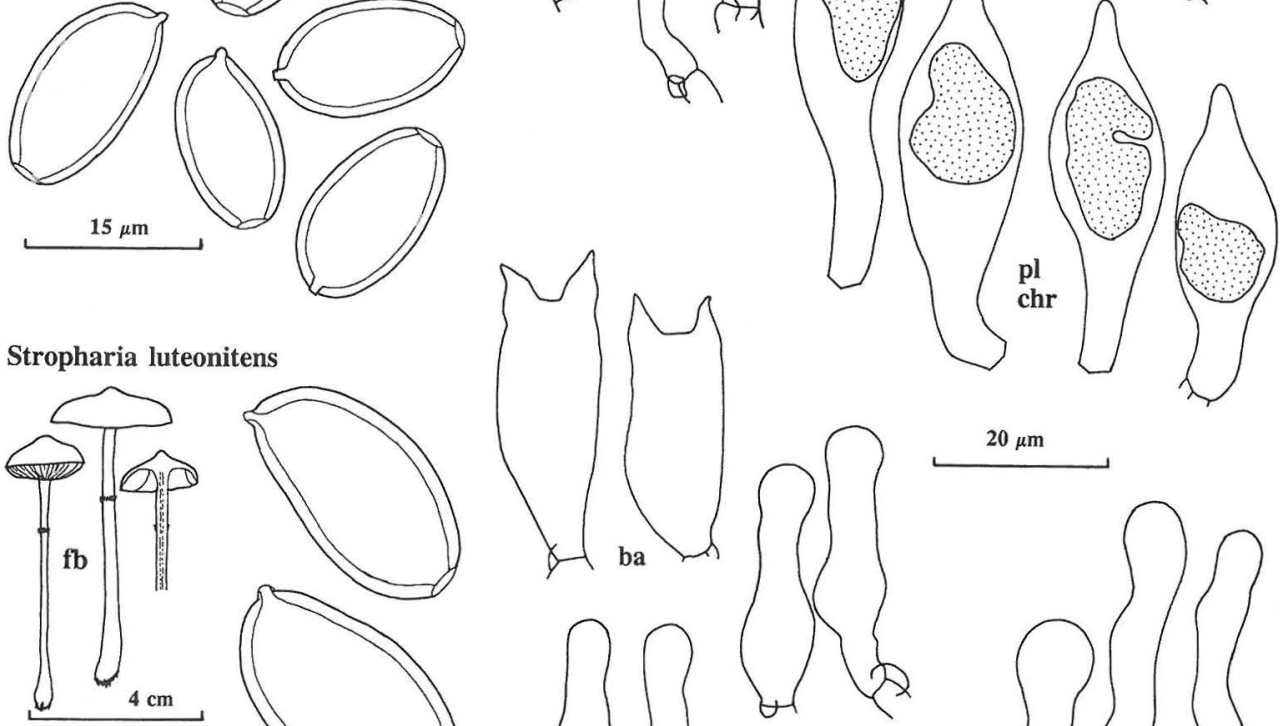

ch
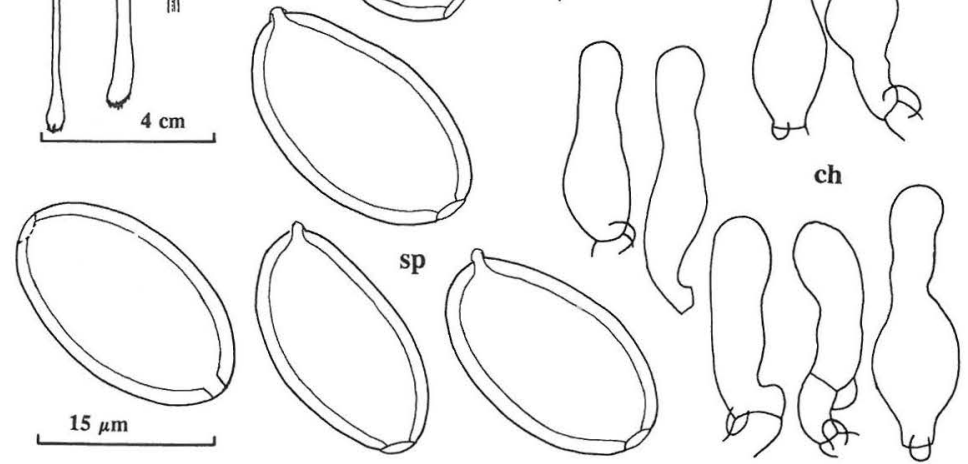

$20 \mu \mathrm{m}$

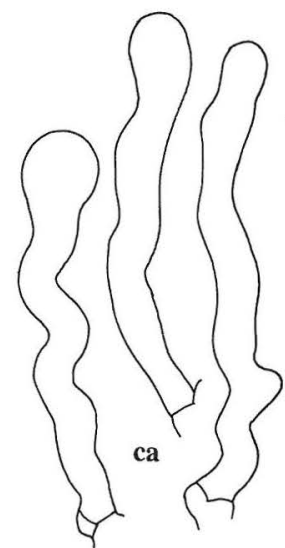

Fig. 5. Fruitbodies and microscopical details. Stropharia arctica: Iceland, Vestur-Húnavatns Sýsla, Ósar Vatnsnesi, Hallgrímsson 9510 (AMNH, type). S. luteonitens: Norway, Buskerud, Nes, Stordal 11146 aquarelle (O, fruitbodies); Finland, Etelä-Häme, Lammi, 1979 Munsterhjelm (H, microscopical details). - ba: basidia, ca: caulocystidia. ch: cheilocystidia, chr: chrysocystidia, fb: fruitbodies, pl: pleurocystidia, sp: spores. Scale: fruitbodies $\times 0.5$, cystidia $\times$ 1000 , spores $\times 1500$. 
ulation has somewhat decreased (Koivisto 1972, Cederlund \& Markgren 1987, Nygren 1987, 1996, Østgård 1987). This history appears well in the material of Stropharia alcis (Fig. 8). Old collections lack completely. Also in Russia (especially in the European part) and in North America (mainly in Canada) the moose population has increased and expanded its range (Whitehead 1972, Kelsall 1987).

Stropharia alcis is common throughout Fennoscandia, where elk is common and abundant (Fig. 10). In the northern part of the area it is nowadays distinctly commoner than $S$. semiglobata. It is obvious that the distribution continues towards the east and to North America, but I have no material from there. Farther south in Europe the species is probably rare or absent owing to the lack of elk.

\section{Discussion}

In the field Stropharia alcis is easily recognized by its habitat. Microscopically the identification is very easy to confirm from the spore size and the form of cheilocystidia. Dried basidiocarps can fairly reliably be identified by examining the gill edge with a dissecting microscope or a hand lens. In S. alcis the edge looks like if covered by white lumps, when in S. semiglobata the gill edge looks evenly minutely echinate or hairy (white).

It is unlikely that any old names would exist for Stropharia alcis, as older mycologists mostly lived outside the distribution area of elk or where elk was very rare at that time.

Specimens examined: Norway. 7 ex. (O), 4 ex. (TRH), 4 ex (TROM), 1 ex. (TUR). Sweden. 17 ex. (H), 7 ex. (S), 3 ex. (UME), 3 ex. (UPS). Finland. 61 ex. (H), 1 ex. (JYV), 2 ex. (KUO), 11 ex. (OULU), 1 ex. (S), 23 ex. (TUR), 6 ex. (TURA). Estonia. 1 ex. (H), 2 ex. (TURA).

\section{Stropharia arctica Kytöv., spec. nova} (Figs. 5, 6-9, 11)

Pileus 0.5-3 cm latus, hemisphaericus, dein convexus, stramineus, viscidus vel glutinosus, stipite 1-5 cm longo, 1-3 mm crasso, cum basi clavata, sub annulo glutinoso et pileo aliquantem pallidiore. Sporae 13.1-16.5 × 7.9-10.0 $\mu \mathrm{m}$, ellipsoideae, violaceo-atrae, poro distincto, centrali, 1.8-2.0 $\mu \mathrm{m}$ lato. Cheilocystidia fasci-culatae, angustae, cylindricae, longae (30-
$75 \mu \mathrm{m})$, basi et apice vix inflato. Chrysocystidia faciales praesentes, in stipite nulla. In fimo, in Islandia et Russia arctica cognita.

Holotypus: Iceland, Vestur Húnavatns Sýsla, Ósar Vatnsnesi, moorland, on dung, 2.IX.1984 H. Hallgrímsson 9510 (AMNH).

Pileus $0.5-3 \mathrm{~cm}$, semiglobose to convex, viscid to glutinous, pale straw yellow, more strongly at the disk. Lamellae arched to subventricose, slightly decurrent, blackish brown with white edge, mostly three lamellulae (one longer, two very short) between the whole gills. Stipe $1-5 \mathrm{~cm}$ long, 1-3 mm thick, at the base to $6 \mathrm{~mm}$ thick, hollow, with a membranous to very thin annulus $0.5-1.5 \mathrm{~cm}$ below the gills; below the ring slightly paler than the pileus, viscid to glutinous, at the top above the ring whitish pruinose, dry. (Above is based on the dried material).

Spores $13.1-16.5 \times 7.9-10.0 \mu \mathrm{m}(\overline{\mathrm{x}}=15.0-15.1 \times$ 8.5-9.0 $\mathrm{mm}, 134$ spores of $2 \mathrm{spec}$.$) , length/width$ ratio $\mathrm{Q}=1.58-1.86(\overline{\mathrm{q}}=1.67-1.76)$, ellipsoid to very slightly ovoidly ellipsoid, very slightly flattened ventrally (adaxially), smooth, bay to dark brick in Melzer's reagent, thick-walled, with some guttules mostly at both ends, germ pore distinct, central, ca. $1.8 \mu \mathrm{m}$ wide.

Basidia broadly clavate, $27-37 \times 9.5-12.5 \mu \mathrm{m}$ (45 bas. of 2 spec.), 4-spored, with broad sterigmata. Pleurocystidia chrysocystidia, 32-50(-58) $\times 10-13.5 \mu \mathrm{m}$ ( 38 chrysoc. of 2 spec.), fusiform, apex broadly rostrate, with yellowish brown inclusion, scarcer than in Stropharia semiglobata, mostly absent at gill edge. Cheilocystidia long and narrow, very narrowly clavate, in form somewhat resembling those of $S$. squamosa, 30-75 $\mu \mathrm{m}$ ( 86 cheiloc. of 2 spec.), with slightly swollen, 3.5$5.5 \mu \mathrm{m}$ thick apex, middle part flexuous, mostly 2.5-3.5 $\mu \mathrm{m}$ thick and base 2,5-5.5 $\mu \mathrm{m}$ thick; abundant, in large, dense fascicles. Between and outside the narrow flexuous cheilocystidia some narrowly lageniform ones with the base up to 11 $\mu \mathrm{m}$ and the middle part to $6 \mu \mathrm{m}$ thick. Gill edge sterile. Caulocystidia on stipe top above the ring like cheilocystidia, 49-80 $\mu \mathrm{m}$ long (49 cauloc. of 2 spec.), in fascicles. Chrysocystidia absent on the whole stipe (both on the slimy part and above the ring).

Cap cuticle an ixocutis with thick slime layer with few, 2-4 $\mu \mathrm{m}$ thick, embedded hyphae, in the lower part somewhat thicker (to $7 \mu \mathrm{m}$ ), finely spirally encrusted. Stipe cuticle an ixocutis as in the 
cap but hyphae more numerous, near the surface 2-4 $\mu \mathrm{m}$ thick, deeper a little thicker (to $5 \mu \mathrm{m}$ ), not or very finely spirally encrusted, encrustation strongest at the stipe base. Clamps present at all septa.

\section{Ecology and distribution}

So far only two specimens of Stropharia arctica are known, one from Iceland (Hallgrimsson 9510, AMNH), the other from Russia, Bolshezemelskaya Tundra (Ohenoja 1996/40, OULU).

The Icelandic specimen has been collected from a moor from dung without information of the animal. The Russian basidiocarps were grown in the tundra on droplets of hare (Lepus timidus). Any Greenlandish or American material has not been seen. Both specimens have been collected in early autumn. More material is needed to clear up the ecology and phenology of the species.

\section{Discussion}

Stropharia arctica is characterized by the medium-sized spores in the group and by long and very narrow, flexuous cheilo- and caulocystidia resembling those of $S$. squamosa. From $S$. semiglobata it differs by smaller spores and lack of chrysocystidia on the stipe, from $S$. alcis by somewhat wider spores and narrower cheilo- and caulocystidia.

The basidiocarps of the two specimens seen by me are very different in their external habit. The Icelandic basidiocarps are fairly large and sturdy when compared with the other materials (e.g. S. semiglobata) from there (but small when compared with those in the Fennoscandian material). The Russian material demonstrates very small basidiocarps. However, the difference may be caused by different dung. Watling \& Gregory (1987) and Arnolds (1982) describe very small $S$. semiglobata basidiocarps on rabbit pellets. Microscopically both specimens are very similar.

Specimens examined: See type. - Russia. Siberia, Tyumen Region, Yamalo-Nenetsia, Bolshezemelskaya Tundra, 1966 Ohenoja 1996/40 (OULU).

\section{Stropharia islandica Kytöv., spec.} nova (Figs. 3, 6-9, 11)

Pileus 1-5 cm latus, late subglobosus, dein plano-convexus, stramineus, viscidus, stipite 2 $5 \mathrm{~cm}$ longo, 2-5 $\mathrm{mm}$ crasso, cum basi leviter clavata, sub annulo distincto viscido et pileo concolore. Sporae 13.4-17.9 × 7.3-10.0 $\mathrm{m}$, ellipsoidae, violaceo-atrae, poro distincto, centrali, 1.6-1.8 um lato. Basidia late clavata $(28-40 \times$ 11-15 $\mu \mathrm{m})$. Cheilocystidia anguste clavata (25-60 $\mu \mathrm{m})$, apice ad $13 \mu \mathrm{m}$ inflato. Chrysocystidia nulla. In fimo, in Islandia cognita.

Holotypus: Iceland, Eyjafjarðar Sýsla, Glerardalur, near the water containers, on horse dung, 11.IX.1968 H. Hallgrimsson 5323 (AMNH).

Pileus $1-5 \mathrm{~cm}$, broadly subglobose to planoconvex, viscid to strongly glutinous, straw yellow, ochraceous at the disk. Lamellae broad, subventricose, slightly decurrent, blackish brownish, without greenish shade, with white edge, mostly three lamellulae (one longer, two short) between the whole gills. Stipe fairly short and stout, 2-5 $\mathrm{cm}$ long, slightly thickening towards the clavate base, $1.8-5.0 \mathrm{~mm}$ thick at the apex, $2.5-7.0 \mathrm{~mm}$ at the base, hollow, with fairly thin but distinct annulus $0.5-1.5 \mathrm{~cm}$ below the gills, straw yellowish and glutinous below and whitish pruinose and dry above the ring zone. (Above $\bar{e}$ is based on dried material).

Spores $13.4-17.9 \times 7.3-10.0 \mu \mathrm{m}(\overline{\mathrm{x}}=14.5-16.7 \times$ 8.2-9.5 $\mu \mathrm{m}, 124$ spores of $7 \mathrm{spec}$.), length/width ratio $\mathrm{Q}=1.65-1.89(\overline{\mathrm{q}}=1.74-1.83)$, ellipsoid to very slightly ovoidly ellipsoid, very slightly flattened ventrally (adaxially), smooth, bay to dark brick in Melzer's reagent, thick-walled, with some guttules mostly at both ends, germ pore distinct, central, 1.6-1.8 $\mu \mathrm{m}$ wide.

Basidia broadly clavate, $28-40 \times 11-15 \mu \mathrm{m}(95$ bas. of 7 spec.), 4-spored, with broad sterigmata. Pleurocystidia (chrysocystidia) absent. Cheilocystidia narrowly clavate, 25-60 um (156 cheiloc. of 7 spec.), with more or less swollen apex, 4-13 $\mu \mathrm{m}$ thick, middle part mostly flexuous, 3-6 $\mu \mathrm{m}$ thick, base 4-9 $\mu \mathrm{m}$ thick; abundant, in large fascicles. Gill edge sterile. Caulocystidia on stipe top above the ring like cheilocystidia but somewhat longer, 36-80 $\mu \mathrm{m}$ ( 86 cauloc. of 7 spec.), in fascicles. 
Fig. 6. Diagram showing the spore size of Stropharia semiglobata, $S$. dorsipora, $S$. alcis, $S$, arctica, S. islandica and $S$. luteonitens. The lines are drawn on the basis of scatter diagrams, and contain $95 \%$ of the spores measured of each species. $x$ axis: length of spores. $y$ axis: width of spores.
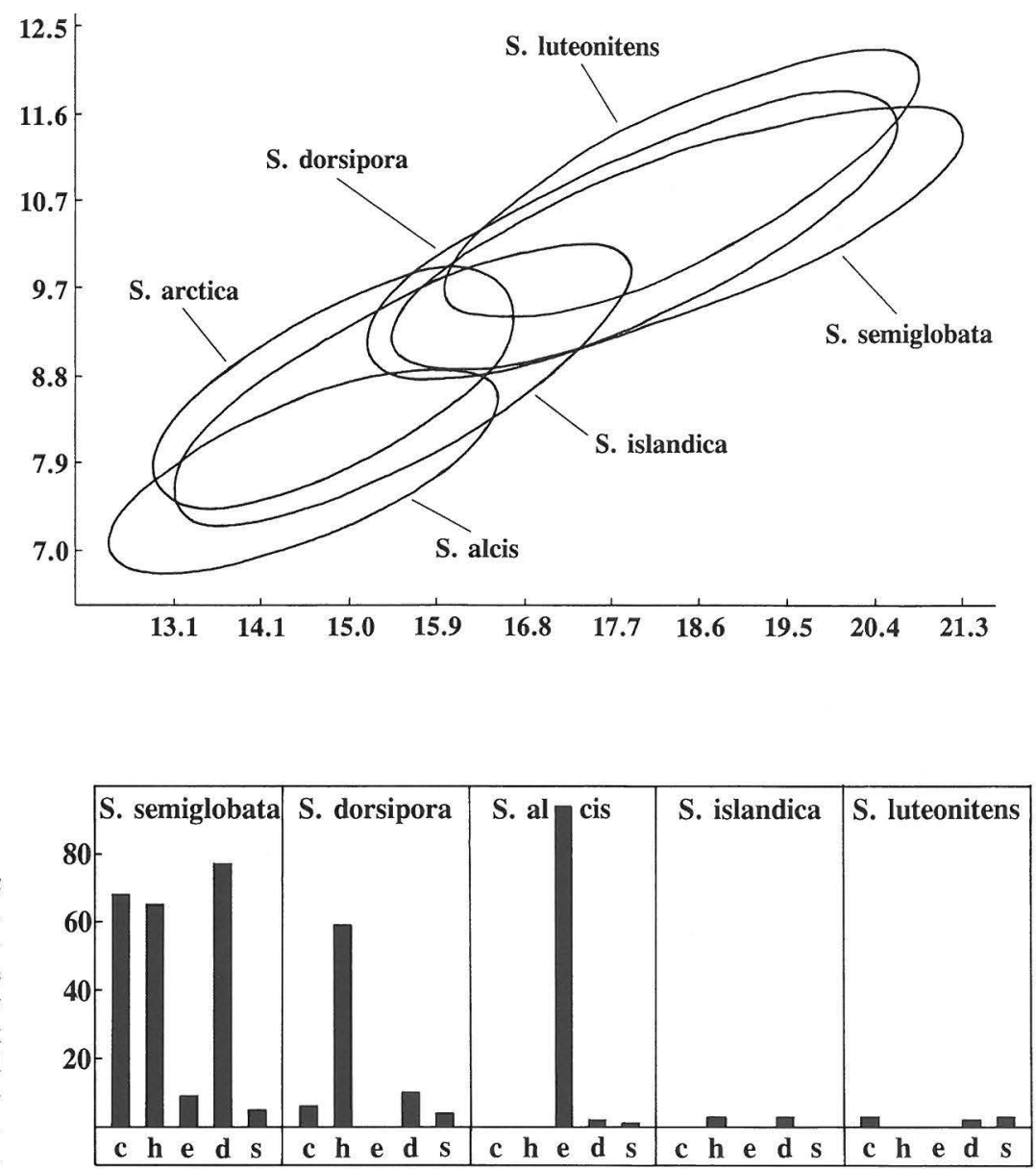

Fig. 7. Ecology of Stropharia semiglobata, S. dorsipora, S. alcis, $S$. islandica and S. luteonitens according to the specimens examined. c: cow dung, h: horse dung, e: elk dung, d: dung only, s: manured soil. Specimens without information of dung excluded. $\mathrm{y}$ axis: numbers of specimens.

Cap cuticle an ixocutis with thick slime layer with few, 2-4 $\mu \mathrm{m}$ thick, embedded hyphae, which in the lower part are somewhat thicker (to $7 \mu \mathrm{m}$ ), finely spirally encrusted. Stipe cuticle an ixocutis as in the cap but hyphae more numerous, near the surface 3-5 $\mu \mathrm{m}$ thick, deeper a little thicker (to $6 \mu \mathrm{m}$ ), finely spirally encrusted, encrustation strongest at the stipe base. Clamps present at all septa.

\section{Ecology and distribution}

Stropharia islandica seems to occur in more os less open land mostly on dung. According to the labels three specimens are from horse dung, three ones from dung and one is without information (Fig. 7). Collections are from the middle of August to the end of September (Fig. 9). The material is fairly recent, the first specimen from the year 1961 (Fig. 8), and chronologically strictly consistent with the Icelandic material of S. semiglobata.

So far Stropharia islandica is known from Iceland only, where it has been collected in a large area in the northern part of the country (Fig. 11). Four of the specimens have been collected as $S$. semiglobata (two mixed collections with the latter one with $P$ silocybe semilanceata, two as $P$. merdaria and one as $P$. coprophila). No specimens from Fennoscandia have been found, 
Fig. 8. Collections of Stropharia semiglobata, S. dorsipora, S. alcis, S. arcti$c a, S$. islandica and S. luteonitens according to the Nordic material examined. $x$ axis: the time from 1840 divided in decades. y axis: numbers of specimens collected in each decade.

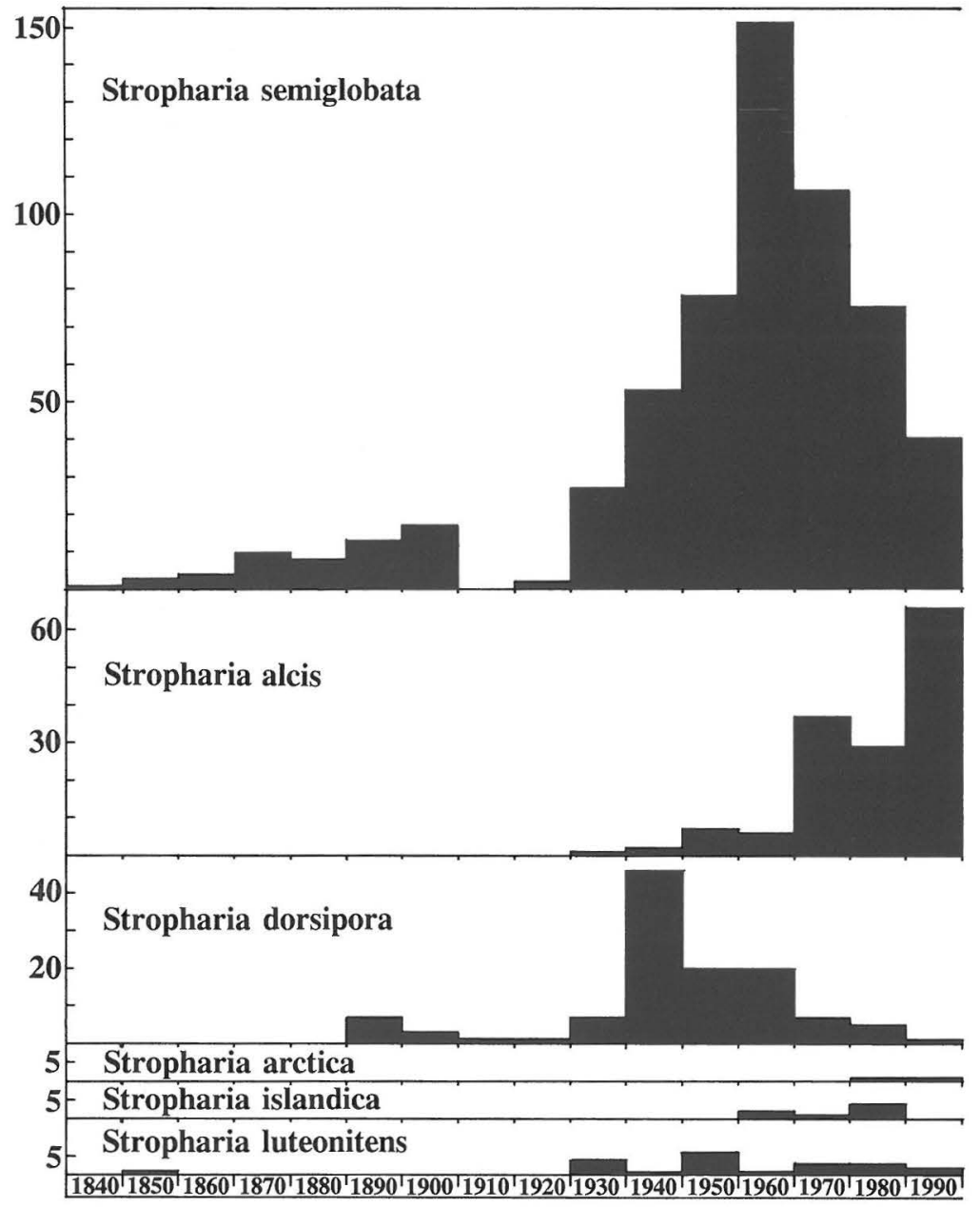

though also the material of Psilocybe merdaria and unidentified Stropharia from BG, TROM, TRH and the Finnish herbaria have been checked in addition to $S$. semiglobata.

\section{Discussion}

Macroscopically Stropharia islandica is characterized by its fairly sturdy external appearance. It seems to be somewhat shorter and wider than $S$. semiglobata and with fairly short and stout stipe (also $S$. semiglobata seems to be distinctly lower in the Icelandic material than in Fennoscandia). The ring seems to be more distinct and persisting than in S. semiglobata.
Microscopically Stropharia islandica is known by the lack of chrysocystidia, by its fairly large cheilocystidia with swollen apex and fairly small spores for the present group.

Stropharia islandica differs from S. luteonitens most easily by the 4-spored basidia and smaller spores. In this respect the species may resemble the 4-spored form of $S$. luteonitens mentioned by Parker-Rhodes (1951), Michael et al. (1985), Guzmán (1983), Watling \& Gregory (1987) and Noordeloos (1996). However, many other differences exist between the latter species. The appearance of S. islandica is sturdier, reddish colours, typical to $S$. luteonitens on the disk, seem to be lacking (colours are rather pale 


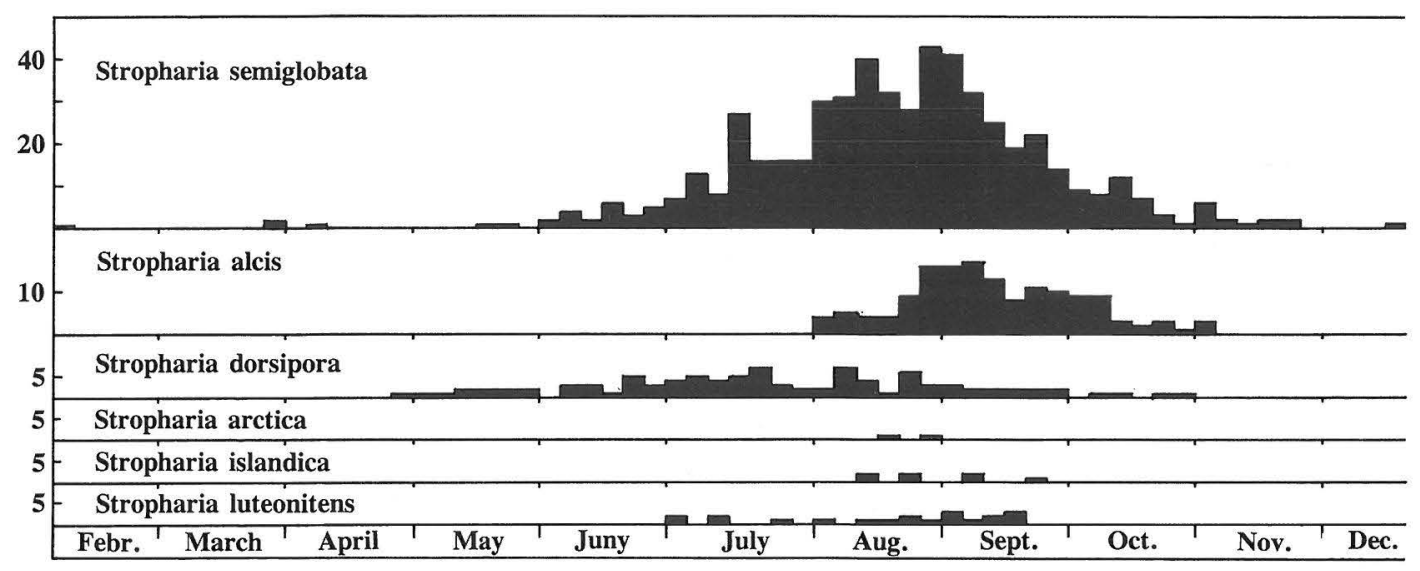

Fig. 9. Fruiting periods of Stropharia semiglobata, S. dorsipora, S. alcis, S. arctica, S. islandica and S. luteonitens in Nordic herbaria according to the specimens examined. $x$ axis: the season from 6.II. to 21.XII. divided in pentads. y axis: numbers of specimens collected in each pentad.

or dirty as in Psilocybe merdaria), ring is more distinct, cheilo- and caulocystidia are larger and germ pore is strictly central and straight. S. islandica clearly represents a different species, not a 4-spored form of S. luteonitens.

Specimens examined: Iceland: Eyjafjarðar Sýsla: See type; Kotárborgir Akureyri, 1984 Hallgrímsson 9557 (AMNH). Norður Múla Sýsla: Droplaugarstað̃ir Fljótsdal, 1988 Hallgrímsson 11861 (AMNH); Möðrudalur á Fjöllum, 1985 Hallgrímsson 10003 (AMNH). Suður Thingeyjar Sýsla: Bakki Tjörnesi, 1983 Hallgrímsson 9245 (AMNH); Mýlaugsstaðir Aðaldal, 1961 Hallgrímsson 674 (AMNH). Vestur Húnavatns Sýsla: Reykir Hrútafirð̈i, 1972 Hallgrímsson 8049 (AMNH).

\section{Stropharia luteonitens (Vahl : Fr.) Quél. (Figs. 5-9, 12)}

Stropharia luteonitens (Vahl : Fr.) Quél., Champ. Jura et Vosges 1:142. 1872. - Agaricus luteonitens Vahl, Fl. Danica 6 (fasc. 18): pl. 1057, fig. 1. 1792; Fr., Syst. Mycol. 1:511, 1821; 3:Index 28. 1832. - Geophila luteonitens (Vahl : Fr.) Quél., Enchir. Fung. 111. 1886. Type: Not typified. - Psilocybe luteonitens (Vahl : Fr.) Park.-Rhodes, Trans. British Mycol. Soc. 34:364. 1951. Stropharia umbonatescens (Peck) Sacc., Syll. Fung. 5:1021. 1887. - Agaricus umbonatescens, Peck, Ann. Rep. N.Y. St. Mus. 30:41. 1878. - Type: U.S.A. New York, Schenevus. Not seen.

Illustrations: Ricken (1915: pl. 63), Lange (1935: pl. 141A), Konrad \& Maublanc (1924: pl. 54), Soc. Catal. Micol. (1983: pl. 95), Michael et al. (1985: 423).

Pileus 1-3 cm, mostly more distinctly and sharply umbonate than Stropharia semiglobata, vis- cid to glutinous, pale straw yellow, reddish brown at the disk, very thin-fleshed, somewhat hygrophanous and translucent striate at the margin. Lamellae broad, subventricose, slightly decurrent, most often three lamellulae (one longer, two very short) between the whole gills, blackish brownish with whitish edge. Stipe slender, somewhat radicating, 3-8(-16) cm long, $1-3 \mathrm{~mm}$ thick, at the base somewhat thicker, with a very thin and soon disappearing annulus $1-4 \mathrm{~cm}$ below the gills, pale yellowish and viscid below, whitish and dry above the ring zone, hollow. Taste should be unpleasant, like that of Tricholoma sulphureum.

Spores $16.3-20.8 \times 9.5-12.2 \mu \mathrm{m}(\overline{\mathrm{x}}=17.3-19.7 \times$ 10.2-11.4 $\mu \mathrm{m}, 333$ spores of 19 spec.), length/ width ratio $\mathrm{Q}=1.60-1.85(\overline{\mathrm{q}}=1.63-1.76)$, ellipsoid to very slightly amygdaliform, often with a very slight suprahilar depression, thick-walled, reddish brown in Melzer's reagent, germ pore ca. 1.8 $\mu \mathrm{m}$ wide, very slightly dorsally oblique (larger and less eccentric than in $S$. dorsipora).

Basidia 23-29 × 11.0-12.5 $\mu \mathrm{m}$ (126 bas. of 13 spec.), 2-spored, without or with very small pedicel. Pleurocystidia (chrysocystidia) absent. Cheilocystidia smaller and less abundant than in the other species treated here, cylindrical to narrowly lageniform, $25-37 \mu \mathrm{m}$ long (320 cheiloc. of 16 spec.), with base 5.5-8,0 $\mu \mathrm{m}$ thick, middle part 3-5 $\mu \mathrm{m}$ thick, straight or slightly flexuous and apex tapering to slightly swollen, 3.0-7.5 $\mu \mathrm{m}$ 


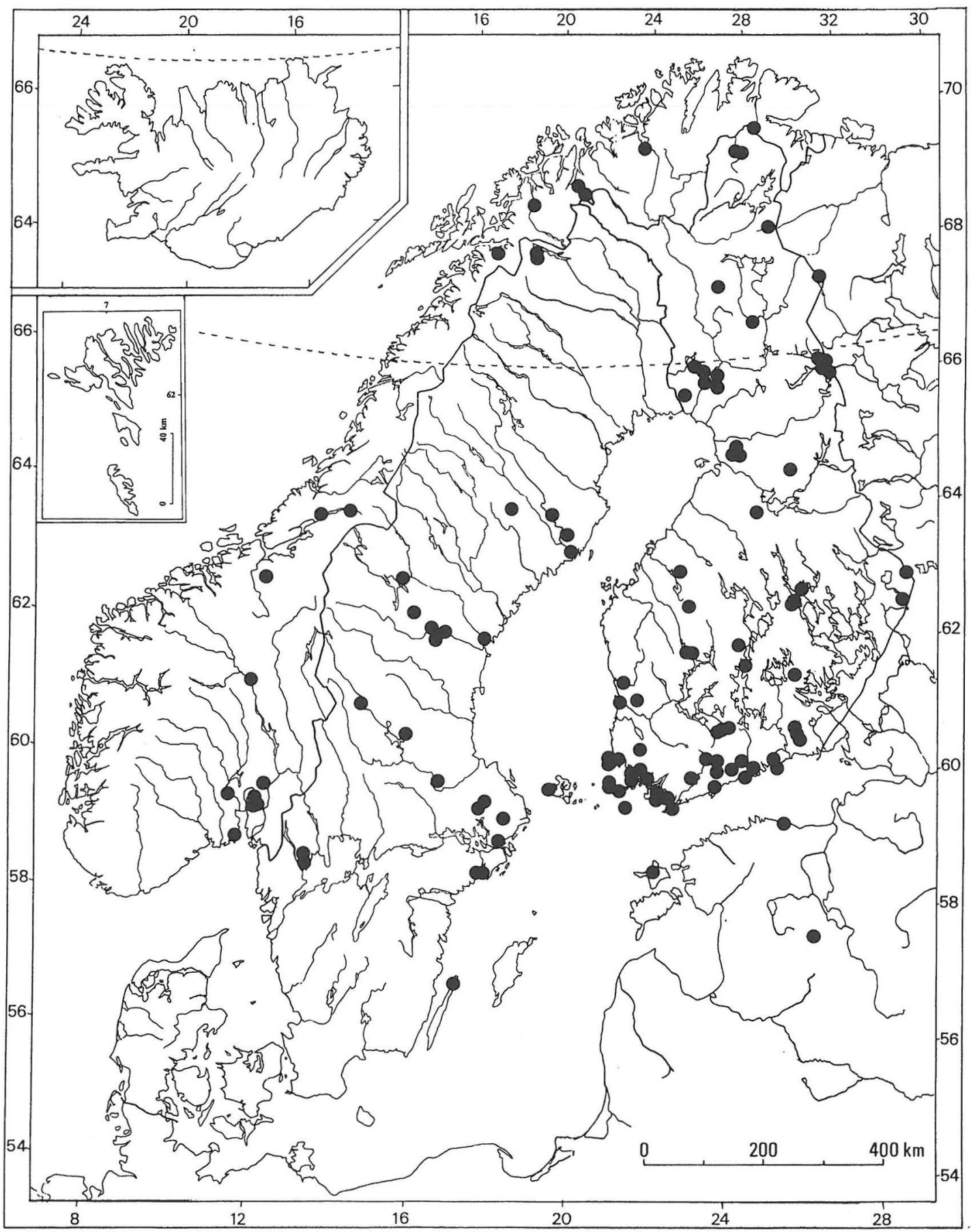

Fig. 10. Distribution of Stropharia alcis in NW Europe according to the material examined. 
Fig. 11. Distribution of Stropharia arctica and $S$. islandica in NW Europe according to the material examined. Dots $=S$. islandica. Squares $=S$. arctica .

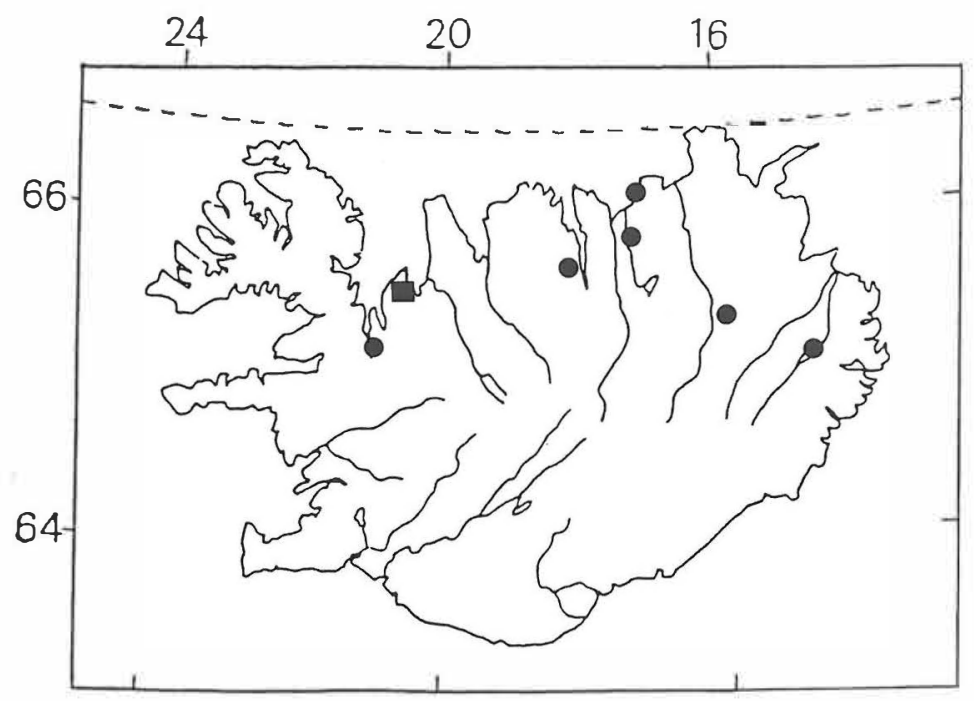

thick. Gill edge sterile. Caulocystidia on stipe top above the ring as cheilocystidia, but somewhat longer $26-53 \mu \mathrm{m}$ (88 cauloc. of 5 spec.) and more variable.

Cap cuticle an ixocutis with slime layer with few, $2-4 \mu \mathrm{m}$ thick, embedded hyphae, in the lower part somewhat thicker (to $7 \mu \mathrm{m}$ ) hyphae, finely spirally encrusted. Stipe cuticle an ixocutis as in the cap but hyphae more numerous, near the surface $2-4 \mu \mathrm{m}$ thick, deeper a little thicker (to $5 \mu \mathrm{m}$ ), finely spirally encrusted, encrustation strongest at the stipe base. Clamps present at all septa.

\section{Ecology and distribution}

Stropharia luteonitens grows in forests, pastures, gardens etc. on manured soil or on decaying dung (cf. Ricken 1915, Lange 1935, Arnolds 1982, Ryman 1992). Rald (1992) emphasizes that the species mostly thrives in extensively used nature and avoids artificially fertilized ground.

The fruiting period of the species seems to be long. Material is scanty but collections are fairly evenly from the beginning of July to the end of September (Fig. 9). Rald's (1992) material is from September and October. According to Arnolds (1982) the species occurs very irregularly, and his records are from October. In the present material the first collection is from the year 1858 (v. Post, $S)$ and since then the species has been collected during all decades from 1930's, but the vast increase of collecting during the last five decades does not at all appear with this species (Fig. 8).

Stropharia luteonitens seems to be rare or very rare everywhere in its range. All the specimens earlier determined as $S$. luteonitens in the Finnish herbaria proved to be other species, but one indetermined Stropharia specimen (EteläHäme, Lammi, 1979 Munsterhjelm, H) is S. luteonitens. From Sweden it has not been recorded by Ryman (1992) or Hallingbäck (1994), but Hallingbäck \& Aronsson (1998) reported the species from $\mathrm{N}$, southern central and SE Sweden. Neither material nor other basis has not been cited. I found 4 old specimens (1858-1952) in the material of S, but only one of them was identified as S. luteonitens. In Denmark it was classified as extinct (Vesterholt \& Knudsen 1990), but has been found again later (cf. Rald 1992). It is known also from Iceland and the Faeroes (Fig. 12).

According to Watling \& Gregory (1987) several records of Stropharia luteonitens are known from Great Britain but the species is rarely found recently. The diminishing trend is seen also in the present material, especially when compared with the very numerous new collections of some other species of the group (Fig. 8). From the Baltic countries it is known from Estonia (Saaremaa, 1993 Kytövuori 93-1270, H) and Lithuania (Urbonas et al. 1986). In Germany and Netherlands it is 


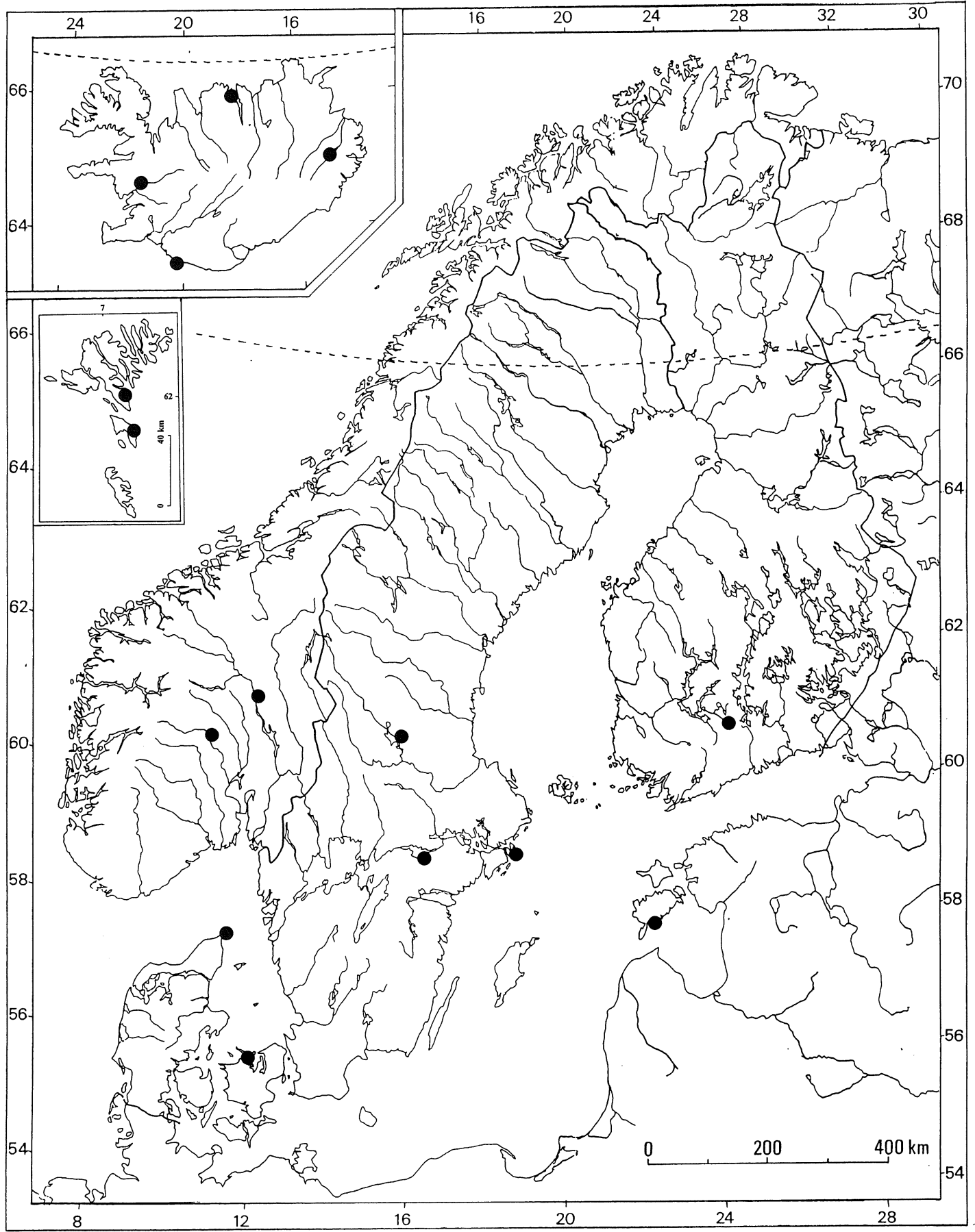

Fig. 12. Distribution of Stropharia luteonitens in NW Europe according to the material examined. 
rare (Kreisel 1887, Krieglsteiner 1991, Arnolds 1982). On grounds of the present material S. luteonitens seems to be somewhat oceanic in its distribution.

\section{Discussion}

Macroscopically Stropharia luteonitens is characterized by small size, slender habit, sharply umbonate pileus and weak ring fairly low on the stipe. Microscopically it is recognized by large spores with slightly eccentric germ pore, 2spored basidia and lack of chrysocystidia. Based on the last character, it is, with $S$. squamosa, $S$. magnivelaris and $S$. percevalii, placed in Psilocybe by many authors. However, S. percevalii has chrysocystidia, even if rare and small and difficult to observe (Kytövuori 1992). It feels unnatural to separate $S$. islandica and $S$. luteonitens from Stropharia or to split the $S$. squamosa group into different genera, based on the presence of chrysocystidia only. Noordeloos (1995), following Smith (1979) and Kühner (1980), suggested to unite Stropharia, Hypholoma and Psilocybe into one genus Psilocybe. I cannot see any reason to such lumping. The problem in fungi are too large and heterogeneous genera, not too small ones.

According to Michael \& al. (1985), Guzmán (1983), Watling \& Gregory (1987) and Noordeloos (1996) Stropharia luteonitens has 4or 2-spored basidia, whereas most other e.g. Konrad \& Maublanc (1924), Lange (1935), Kühner \& Romagnesi (1953), Arnolds (1982) and Ryman (1992) record 2-spored basidia only. ParkerRhodes (1951) knows 4-spored basidia only, but his description is also otherwise doubtful (dry stipe, small spores, $13 \times 8 \mu \mathrm{m}$ ) and may represent another species. In the present material no 4spored forms were found. S. islandica has 4spored basidia, but it differs on the basis of many other characteristics, too (cf. above), and does not belong to $S$. luteonitens.

Specimens examined: Iceland. Eyjafjarðar Sýsla: Hóll Upsaströnd, 1967 Hallgrímsson 3207 (AMNH). Norður Múla Sýsla: Skriðuklaustur Fljótsdal, 1987 Hallgrímsson 11506 (AMNH). Hredavatn, 1984 Elborne SAE-111ISL (C). Vestmannaeyjar, 1935 Christiansen (aquarelle only, very typical, C). Denmark. The Faeroes: Sand $\varnothing$, Skaalehoved, 1938 M $\phi$ ller (C), Strøm $\varnothing$, Tuorshavnöy, 1938 Møller (C). Nordjylland: Skagen, Pælebakke Klit, 1983 Elborne SAE 0854 (C). Sjælland \& surrounding islands: Sjælland, Odsherred, Bjergene, 1992 Bruun \&
Ejrnas EB010992-1 (C). Norway. Opland: Øyer, Bottrudhaugen, 1979 Stordal 19933 (O); Sjøseterfjell, 1979 Stordal 19943 (O). Buskerud: Nes, Nystølen-vollen, 1955 Stordal 10179, 10180, 10181 (O); Nystølen, 1958 Stordal 11146 (O). Sweden. Södermanland: Julita, Äs, 1858 von Post (S), Djurö, Runmarö, Vånö, 1948 Rydberg (S); Runmarö, 1952 Haglund (S). Dalarna: Rättvik, Vikarbyn, 1936 Cortin (S). Finland. EteläHäme: Lammi, Jahkola, Mataramäki, 1979 Munsterhjelm $(\mathrm{H})$. Estonia, Saaremaa, Abruka, 1993 Kytövuori 93-1270 (H). Italy. Two specimens in Herb. Bresadola, 1902, 1903 (S).

\section{Excluded taxa}

Stropharia semiglobata subsp. siccipes P. Karst., Meddel. Soc. Fauna Fl. Fennica 9:46. 1882. - Lectotype: Finland, Etelä-Häme, Tammela, Mustiala, 6.VIII.1881 P.A. Karsten (H), selected here, = Psilocybe merdaria group).

Acknowledgements. I thank Prof. Teuvo Ahti, Ph.D., for valuable suggestions regarding the manuscript. I am also indebted to the curators of the herbaria for loans of the material, Mrs. Esteri Ohenoja, Ph.D., and Mr. Jan Vesterholt, for valuable specimens, Mrs. Tuire Nygren, Ph.D., for the literature referring to elk, and Mrs. Marja Koistinen, Cand. Phil., for drawing facilities.

\section{References}

Arnolds, E. 1982: Ecology and coenology of macrofungi in grasslands and moist heathlands in Drenthe, the Netherlands. 2-3. - Biblioth. Mycol. 90:1-501 + 8 pls.

Bresadola, J. 1931: Iconographia mycologica 17. - Pls. 801-850. Mediolani.

Cederlund, G. \& Markgren, G. 1987: The development of the Swedish moose population, 1970-1983. Swedish Wildlife Res. Suppl. 1, 1987:55-62.

Cooke, M.C. 1871: Handbook of British fungi 1. -488 pp. London.

Cooke, M.C. 1884-1886: Illustrations of British fungi (Hymenomycetes) 4. - Pls 485-638. London.

Dähncke, R.M. 1993: 1200 Pilze in Farbfotos. - 1179 pp. Stuttgart.

Esteve-Ravenós, F. \& Barrasa, J.M. 1995: Coprophilous Agaricales from Spain II. The genus Stropharia and Stropharia dorsipora sp. nov. - Rev. Iberoamer. Micol. 12:70-72.

Fries, E. 1821: Systema mycologicum 1. $-57+520$ pp. Lundae.

Fries, E. 1836-1838: Epicrisis systematicis mycologici. - 12+610 pp. Upsaliae.

Fries, E. 1874: Hymenomycetes Europaei sive epicriseos systematis mycologici. - 755 pp. Upsaliae. 
Gillet, C.-C. 1978-1890: Les Champignons qui croissent en France. Description et iconographie, propriétés utiles ou vénéneuses. -828 pp. +738 pls. Paris.

Guzmán, G. 1983: The Genus Psilocybe. - Beih. Nova Hedw. 74:1-439 + pls. 2, 3, 7, 8, 41-76.

Hallingbäck, T. 1994: Ekologisk katalog över storsvampar. - 213 pp. Uppsala.

Hallingbäck, T. \& Aronsson, G. (eds.) 1998: Ekologisk katalog över storsvampar och myxomyceter. 2nd ed. - 239 pp. Uppsala.

Holmgren, P.K., Holmgren, N.H. \& Barnett, L.C. 1990: Index herbariorum 1. The herbaria of the world. 8th ed. - Regnum Vegetabile 120: 1-693.

Karsten, P.A. 1882: Symbolae ad mycologiam fennicam 9. - Meddel. Soc. F. Fl. Fennica 9:39-56.

Kauffman, C.H. 1918: The Agaricaceae of Michigan. Mich. Geol. Biol. Survey 26, Biol. Ser. 5, 1:1-924.

Kelsall, J.P. 1987: The distribution and status of moose (Alces alces) in North America. - Swedish Wildlife Res. Suppl. 1, 1987:1-10.

Koivisto, I. 1972: Hirvi. - In: Siivonen, L. (ed.): Suomen nisäkkäät 2. 435 pp. Helsinki.

Konrad \& Maublanc 1924-1930: Icones selectae fungorum 1. - Pls 1-100. Paris.

Kreisel, H. (ed.) 1987: Pilzflora der Deutschen Demokratischen Republik. Basidiomycetes (Gallert-, Hut- und Bauchpilze). - 281 pp. Jena.

Krieglsteiner, G.J. 1991: Verbreitungsatlas der Grosspilze Deutschlands (West) 1b. - 421-1016. Stuttgart.

Kühner, R. 1980: Tableau synoptique de la classification proposée pour les hymenomycetes agaricoides d'Europe. - Bull. Soc. Linn. Lyon, num. spec. 49:11027.

Kühner, R. \& Romagnesi, H. 1953: Flore analytique des champignons supérieurs. $-14+557$ pp. Paris.

Kytövuori, I. 1992: Rantakaulussieni ja kumppanit, Stropharia squamosa-ryhmä. (English summary: Stropharia squamosa group in Finland). - Sienilehti 44:96-103.

Lange, J.E. 1923: Studies in the agarics in Denmark 5. Dansk Bot. Archiv 4(4):1-58 + 2 pls.

Lange, J.E. 1935-40: Flora Agaricina Danica 1-5 $122+24$ pp., 200 pls. Copenhagen.

Michael, E., Henning, B. \& Kreisel, H. 1985: Handbuch für Pilzfreunde 4. Blätterpilze - Dunkelblättler. 3rd ed. -488 pp. Stuttgart.

Moser, M. 1983: Die Röhrlinge und Blätterpilze. - In: Gams, H.: Kleine Kryptogamenflora IIb/2.2. 5th ed. 533 pp. Stuttgart.

Noordeloos, M.E. 1995: Notulae ad Floram Agaricinam Neerladicam 23. Psilocybe and Pholiota. - Persoonia 16:127-129.

Noordeloos, M.E. 1996: Notities over de Strophariaceae 3. De meststropharia en verwante soorten in Nederland. - Coolia 39:148-153.

Nygrén, T. 1987: The history of moose in Finland. Swedish Wildlife Res. Suppl. 1, 1987:49-54.

Nygrén, T. 1996: Hirvi (Alces alces). - In: Lindén, H., Hario, M. \& Wikman, M. (eds.): Riistan jäljille: 103108. Helsinki.

Ohenoja, E. 1976: Kaulussienet - Stropharia. - In: U1vinen, T. (ed.): Suursieniopas: 148-149. Helsinki.
Parker-Rhodes, A.F. 1951: The basidiomycetes of Skokholm Island. 6. Observations on certain uncommon species and varieties. - Trans. British Mycol. Soc. 34:360-367.

Phillips, R. 1981: Mushrooms and other fungi of Great Britain and Europe. - 288 pp. London.

Quélet, L. 1872: Les champignons du Jura et des Vosges 1. - Mém. Soc. Emul. Montbéliard. Sér. 2, 5:43-332+ 23 pls.

Quélet, L. 1886: Enchiridion fungorum in Europe media et praesertim in Galliae vigentium. - 352 pp. Lutetiae.

Rald, E. 1992: Usædvanlige danske svampefund. Nye fund af slimstokket nøgenhat (Psilocybe luteonitens). - Svampe 25:31-32.

Rea, C. 1922: British basidiomycetes. A handbook to the larger british fungi. - 799 pp. Cambridge.

Ricken, A. 1915: Die Blätterpilze (Agaricaceae) Deutschlands und der angrenzenden Länder, besonders Oesterreichs und Schweiz 1-2. - 480 pp., 7 pp. +112 pls. Leipzig.

Ryman, S. 1992: Stropharia. - In: Hansen, L. \& Knudsen, H. (eds.): Nordic macromycetes 2:267-269. Copenhagen.

Ryman, S. \& Holmåsen, I. 1984: Svampar en fälthandbok. - 718 pp. Stockholm. (Finnish ed.: 1987: Suomen ja Pohjolan sienet. Helsinki).

Saccardo, P.A. 1887: Sylloge hymenomycetum omnium hucusque cognitorum 5. - 1146 pp. New York - London.

Schumacher, C.F. 1803: Enumeratio plantarum in partibus Sællandiæ septentrionalis et orientalis 2. -489 pp. Hafniae.

Smith, A.H. 1979: Generic relationships within Strophariaceae of the Agaricales. - Taxon 28:19-21.

Societat Catalana de Micologia (ed.) 1983: Bolets de Catalunya. II. Col-lecció. - 50 pls. Barcelona.

Urbonas, V., Kalamees, L., Lukin, V. 1986: Conspectus florum Agaricalium fungorum (Agaricales s.1.) Lithuaniae, Latviae et Estoniae. - 139 pp. Vilnius.

Vesterholt, J. \& Knudsen, H. 1990: Truede storsvampe i Danmark - en rødliste. - 64 pp. Søborg.

Watling, R. \& Gregory, N.M. 1987: British fungus flora 5: Strophariaceae / Coprinaceae p.p. - 121 pp. Edinburg.

Whitehead, G.K. 1972: Deer of the world. - London.

Østgård, J. 1987: Status of moose in Norway in the 1970's and early 1980's. - Swedish Wildlife Res. Suppl. 1, 1987:63-68.

\section{Received on 2 June 1999}

